\title{
Do chief sustainability officers and CSR committees influence CSR-related outcomes? A structured literature review based on empirical-quantitative research findings
}

\author{
Patrick Velte ${ }^{1}$ (D) Martin Stawinoga ${ }^{2}$
}

Accepted: 12 October 2020 / Published online: 26 November 2020

(C) The Author(s) 2020

\begin{abstract}
Although an increasing amount of empirical research has been linked to the impact of management control and governance on corporate social responsibility (CSR) issues since the financial crisis of 2008/09, heterogeneous results have characterised this research field. Regarding the group level of corporate governance, the efficacy of board committees (e.g., audit, compensation or CSR committees) has been included in recent research designs. However, analyses of corporate governance at the individual level are related to the effects of top management members [e.g., chief executive officer (CEO), chief financial officer (CFO) or chief sustainability officer (CSO)] on CSR outcomes. This paper aims to convey a detailed understanding of sustainable management control's impact as CSR-related board expertise. In more detail, we focus on the influence of both CSR committees and CSOs on three CSR measures mainly analysed in empirical-quantitative research: (1) CSR reporting; (2) CSR assurance (CSRA); and (3) CSR performance. We motivate our analysis with increased relevance from practical, regulatory and research perspectives, and we employ a systematic literature review of the symbolic vs. substantive effects of sustainability-related board composition. Based on our theoretical model (legitimacy theory, stakeholder theory and upper-echelons theory), we selected 48 quantitative peer-reviewed empirical studies on this research topic. Our analysis shows that CSR committees positively influence CSR reporting and performance. Thus, there are indications that the implementation of a CSR committee is not a symbolic act, but instead substantively contributes to CSR activities. However, in light of inconclusive empirical research results and a lack of studies that have analysed CSO-related effects, a notable research gap has been identified. Moreover, we note the main limitations of prior research in this review and develop an agenda with useful recommendations for future studies.
\end{abstract}

Keywords CSR committee - Chief sustainability officer (CSO) - CSR reporting · CSR performance $\cdot$ CSR assurance $\cdot$ Board expertise

Extended author information available on the last page of the article 
Jel classifications M41 $\cdot$ M48 - Q3 - Q56

\section{Introduction}

Since the financial crisis of 2008/09, unethical and obscure management strategies, which include greenwashing and information overload behaviour, have reduced stakeholder trust in public interest entities' (PIEs') activities in corporate social responsibility (CSR) ${ }^{1}$ significantly (Fassin and Gosselin 2011). Regarding increased research on business case(s) for CSR (Reinhardt et al. 2020; Salzmann et al. 2005), firm value substantially may be affected negatively through damage to firm reputation as a consequence of corporate irresponsibility. Sustainable management control regarding CSR-related board expertise represents a strategy to decrease conflicts of interest between management and different stakeholder groups, and to strengthen firm reputation (e.g., Feder and Weißenberger 2019; Ghosh et al. 2019; Johnstone 2019; Lingnau et al. 2019).

In modern sustainable management systems, institutionalised sustainabilityrelated board expertise is represented mainly by two mechanisms: CSR committees and chief sustainability officers (CSOs), who manage CSR issues. The implementation of both CSR committees and CSOs remains voluntary from an international perspective (Jaggi et al. 2018b). CSOs are senior executives in top management teams who are explicitly responsible for CSR issues within a specific company (Fu et al. 2020; Strand 2013). A CSO's key goal is to improve working conditions and safety procedures in the supply chain and to foster products and services that address social and environmental issues (Strand 2013, 2014). As the CSO may take on different levels of responsibility in the corporate hierarchy, a CSO's authority may differ substantively across organisations (Miller and Serafeim 2014). This leads in practice to different ways in which the CSO may promote an entity's CSR strategy. If the Chief Executive Officer (CEO) or Chief Financial Officer (CFO) serves simultaneously as the entity's CSO, the CSO may serve in a prominent and powerful position within the company to foster its CSR activities.

Next to CSOs, CSR committees make social and/or environmental recommendations to boards of directors and assist board members in their function. The inclusion of institutionalised sustainability-related board expertise is gaining in importance as firms are no longer held responsible solely for generating profits and pleasing shareholders, but also for caring about other non-shareholding stakeholders' goals regarding the entity's environmental and social performance (e.g., employees, customers and suppliers). Recent corporate scandals, such as Volkswagen's (VW) 'Dieselgate affair' (Nagel et al. 2019), indicate that unethical behaviour within boards of directors significantly reduces the respective companies' reputations, as well as those of other related firms within the same industry.

\footnotetext{
1 Based on a content analysis of existing CSR definitions, Dahlsrud (2008) shows that CSR builds up regularly in five dimensions (environmental, social, economic, stakeholder and voluntariness).
} 
In recent years, empirical research on the link between management control and governance variables, and CSR outputs has grown (Hussain et al. 2018). Considering that sustainability-related board expertise can be realised through two main strategies, the implementation of CSR committees and CSOs represents modern board composition variables. Although this topic is also of increased relevance for research, practice and regulatory initiatives, we still lack a systematic understanding of how the three main CSR outputs (CSR reporting, CSR assurance (CSRA) and CSR performance) are affected from an empirical-quantitative perspective. Prior research designs and results are rather heterogeneous, stressing the unclear consequences from implementation of CSR committees and CSOs, and their composition (Al-Shaer and Zaman 2019; Burke et al. 2019; DixonFowler et al. 2017; Hussain et al. 2018; Kanashiro and Rivera 2019; Peters et al. 2019; Rodrigue et al. 2013; Strand 2013, 2014; Wiengarten et al. 2017). Institutionalised sustainability-related board expertise via CSOs or CSR committees may represent either symbol gestures for companies (related to the risk of greenwashing) or may contribute substantively to companies' CSR activities (management's intrinsic motivation). Thus, CSR committees and CSOs might be related positively or negatively to CSR outputs or may not significantly impact CSR activities and the trust-building effect for stakeholders.

Existing literature reviews and meta-analyses do not focus on these issues, but rather rely on other, more 'traditional' measures of board composition, e.g., independence, diversity, activity, size or CEO duality (Dienes et al. 2016; Elsakit and Worthington 2014; Fifka 2012; Guan and Noronha 2013; Hahn and Kühnen 2013; Jain and Jamali 2016; Malik 2015; Rao and Tilt 2016). Here, we explain how our setting differs from prior literature reviews. Guan and Noronha (2013) focussed on studies conducted by Chinese researchers without any link to corporate governance issues and other countries. Fifka's broad CSR review (2012) was structured mainly around countries or regions and was not particularly focussed on corporate governance. Hahn and Kühnen (2013) stressed that firm- and country-related governance issues comprise central research gaps in empirical CSR research, but they did not analyse these studies in detail. Elsakit and Worthington's review (2014) relied on selective studies on specific corporate governance issues, namely multiple directorships, board independence and foreign diversity. Malik (2015) took a broader view of CSR activities and provided an overview of selective research studies on boards and ownership structure. Dienes et al. (2016) analysed the 'drivers' of sustainability reporting. Next to 'corporate governance structure', other determinants (e.g., capital structure, media visibility) also were included. The review by Rao and Tilt (2016), with respect to a broader view on CSR, includes board composition as one among other elements. Jain and Jamali (2016) presented a research structure for broad multilevel corporate governance mechanisms. The authors analysed every corporate governance level, as well as a matching of CSR. Velte (2017) focussed on the link between board composition on CSR reporting without including other corporate governance determinants and other CSR proxies. These aforementioned reviews did not mention or explain the link between CSR committees, CSOs and CSR effects. Thus, we see a major research gap, as research on this topic has increased over the years and indicates the presence of inconclusive empirical results regarding 
symbolic and substantive use of sustainability-related board expertise. As the fundamental role of CSOs and CSR committees is to increase CSR awareness within firms, our literature review aims to focus on the link between CSR-related board expertise and CSR outputs.

We contribute to this emerging research field by offering a systematic literature review on the impacts from CSR-related board expertise on CSR outputs. These impacts are categorised systematically and critically discussed. Based on this analysis, gaps can be identified and discussed. Thus, this review aims to present the current state of research and identify research gaps.

Our systematic literature review comprises four main steps. First, we examine a broad variety of finance and accounting, management, business ethics and sustainability journals to decrease the risk of missing important analyses. Second, we clearly describe our exclusion criteria to increase our sample selection's transparency. Third, we present a detailed overview of prior results to get a better understanding of heterogeneity in this increasingly relevant research topic. Fourth, we identify key limitations and research gaps, and present useful recommendations for future research.

Regarding prior literature reviews, CSR activities can be differentiated by two main proxies: CSR performance (van Beurden and Gössling 2008) and CSR reporting (Dienes et al. 2016). These variables mainly address the relevance of an entity's CSRrelated activities for stakeholders. As CSR reporting usually is linked with decreased objectivity, stakeholders demand reliable reporting. Thus, assurance of CSR reports represents a useful tool through which to gain legitimacy and build trust (Velte and Stawinoga 2017a). As these three variables have been used as the most important proxies in prior research on CSR committees and CSOs, reflecting the usefulness of decisions in CSR strategies, we differentiate these three CSR topics in our literature review. Furthermore, these CSR categories are of particular relevance for future research settings and the development of practical implications as well. Thus, we employed the following structure:

1. external publication of CSR reports and their quality (CSR reporting),

2. external review of CSR reports by an independent third party (CSRA),

3. CSR performance (both CSR in total and environmental performance, e.g., based on external databases or individual disclosure scores based on content analyses).

We found that prior empirical-quantitative research mainly stresses CSR committees' positive impact on CSR reporting and performance. Thus, there are indications that the implementation of CSR committees does not represent a symbolic board strategy (greenwashing policy), but rather may enhance CSR degree (intrinsic motivation) substantively. However, empirical extant research on other CSR measures, as well as how CSOs affect CSR activities, is scant. Overall, our literature review extends and complements prior research on the link between corporate governance and CSR (e.g., Elsakit and Worthington 2014; Fifka 2012; Guan and Noronha 2013; Hahn and Kühnen 2013; Jain and Jamali 2016; Rao and Tilt 2016). 


\section{Conceptual background}

\subsection{Theoretical background}

\subsubsection{Definition of CSR committees and CSOs}

In our literature review, we define CSOs as top management team members and executives who are primarily responsible for issues related to CSR within an entity (Fu et al. 2020; Strand 2013, 2014). Prior management research has focussed mainly on CEOs, who are responsible for overall strategies and market growth opportunities, as well as on CFOs' role regarding entities' financial risks and accounting matters. Nevertheless, both positions usually are not related to CSR issues (Peters et al. 2019). Thus, to an increasing extent, firms hire CSOs to implement entities' CSR strategies or extend CEOs and CFOs' roles. We are aware of the fact that this position has other titles (e.g., chief ethics officer, chief environmental officer, chief social officer or chief CSR officer), and that their responsibilities may vary in business practice. Moreover, in this analysis, we define CSR committees as corporate subcommittees of boards of directors that make social and/or environmental recommendations to the boards and assist board members in their CSR-related functions (Dixon-Fowler et al. 2017; Orazalin 2020). Thus, the implementation of CSR committees in an assistant role for boards (Garcia-Blandon et al. 2020) should lead to increased CSR-related board efficiency and CSR expertise. In line with our conclusions about CSOs, different labels with varying responsibilities for CSR committees exist in business practice (e.g., ethics committee, sustainable development committee, environmental committee, social committee, health and safety committee or sustainability committee) (Baraibar-Diez and Odriozola 2019).

Generally, CSOs and CSR committees should formulate, execute and supervise a company's CSR strategy as part of corporate board duties (Fu et al. 2020). Their goal is to critically review business practices, analyse environmental and social needs, and formulate strategies that align sustainable development with financial profits. Moreover, CSOs and CSR committees also are responsible for stakeholder relations management, including promotion of CSR culture within the company (Miller and Serafeim 2014). CSOs and CSR committees can signal a firm's commitment to CSR management (Spence 1973). Thus, the firm creates these positions to include CSR aspects in its business model and risk management system (Fu et al. 2020; Strand 2013, 2014). However, CSOs and CSR committees also may function merely to take symbolic actions to meet stakeholders' expectations and enhance public image and financial outputs as greenwashing policy. Thus, substantial improvements in CSR may not be realised, and it remains unclear under which conditions CSOs and CSR committees reflect substantive CSR actions as intrinsic motivation among top management, or merely represent a symbolic function (Peters et al. 2019). Generally, intrinsic or extrinsic motivations to implement CSOs and CSR committees are rather complex. We mainly refer to legitimacy theory, stakeholder theory and upperechelons theory to explain our main CSR categories for our literature review. 


\subsubsection{Legitimacy theory}

A common way to bundle expertise within a board is to create specific committees and top manager positions with specific functions (Harrison 1987). While companies have established a variety of committees, and their effects on different performance measures - e.g., audit and nomination committees (Abbott et al. 2004; Bruynseels and Cardinaels 2014; Ruigrok et al. 2006)—have been analysed widely, new types of committees are gaining relevance in practice and research. In this context, the CSR committee is gaining relevance as companies try to align their expertise, especially regarding environmental and social aspects of their activities. In line with CSR committees, top management also can decide to implement a CSO position.

The establishment of CSR committees and CSOs, and the expected effects on CSR outputs, may be explained through legitimacy theory. Based on this theory, through a social contract (Shocker and Sethi 1973), a company must fulfil the respective society's values and expectations. As societal expectations may change (Deegan 2002) and currently have been changing towards CSR-related issues, the company must establish suitable mechanisms through which to gain legitimacy for CSR orientation of corporate activities (Dyllick and Muff 2016).

One way to gain CSR-oriented legitimacy (Patten 2019) is to establish a CSR committee and/or a CSO position within a company, as this board expertise may encourage a company to prepare an appropriate CSR report voluntarily, and in so doing, improve its CSR-related reputation. Nevertheless, CSR committees and CSOs also can be linked with low-quality CSR reports, including symbolic CSR-related activities, or 'boilerplate' information (Jaggi et al. 2018a). Furthermore, CSR committees and CSOs play a monitoring role within a company regarding CSR-related issues.

Accordingly, a CSR committee and CSO may foster a decision to conduct a thirdparty review of a CSR report (CSRA; Peters and Romi 2015; Prinsloo and Maroun 2020), as this assurance engagement may increase the CSR report's credibility and illustrate the efficacy of the company's CSR-related monitoring mechanisms. However, this assurance engagement may not expand its credibility if CSR-related monitoring mechanisms are not properly designed or if engagement is limited to specific parts of the CSR report.

Furthermore, firms' CSR performance may improve, as the CSR committee and the CSO have specific expertise regarding social and environmental aspects, and fulfilling these issues boosts the firm's reputation and attraction among stakeholders. Nevertheless, the company's legitimacy may suffer if the CSR committee and the CSO act only in a symbolic way in response to CSR-related concerns without achieving specific CSR-related targets (Peters and Romi 2015). Additionally, if the CSR committee and the CSO do not include relevant CSR expertise, the legitimising effect may be only a symbol of a commitment towards CSR to satisfy stakeholders' demands (Peters and Romi 2015).

To sum up, according to legitimacy theory, CSR committees and CSOs can impact CSR reporting, CSRA and CSR performance significantly. However, as 
legitimacy theory explains, the use of sustainability-related board expertise may have positive and negative impacts on CSR outputs.

\subsubsection{Stakeholder theory}

Based on stakeholder theory (Freeman 1984), an entity must fulfil different stakeholder groups' expectations (Freeman et al. 2010). Considering that these expectations may differ and might be multiple and sometimes conflicting (Fernando and Lawrence 2014), a further classification model seems appropriate (Mitchell et al. 1997). Based on the classification model that Mitchell et al. (1997) suggested, stakeholder attributes can be structured in power, legitimacy and urgency, and stakeholders can be categorised under seven types. This categorisation indicates the need for dynamic stakeholder relations management and a careful evaluation of which types of stakeholders may prefer implementation of CSR committees and CSOs and which interests are related to the implementation. Due to the experience of boards of directors in general (Jamali et al. 2008), and the CSR committee and CSO in particular, regarding CSR-related aspects, these institutions may identify the legitimate claims of different stakeholder groups systematically regarding a company's sustainabilityrelated activities. Additionally, the CSR committee and CSO regularly respond to different concerns about CSR-related aspects of different stakeholder groups.

One corporate governance mechanism to address different stakeholders' legitimate claims (Jain and Jamali 2016) is to publish a CSR report (Fernando and Lawrence 2014; Pucheta-Martinez and Gallego-Alvarez 2019) and guarantee an appropriate quality level of CSR disclosure. Based on this publication, the CSR committee and CSO illustrate to affected stakeholder groups how their CSR-related expectations have been addressed. Furthermore, by publishing this report, the CSR committee and CSO can show how they have conducted their monitoring activities regarding CSR-related aspects and management's realisation of CSR activities. Although the publication of a CSR report is an instrument used to reduce information asymmetries between management and different stakeholder groups, due to this report's voluntary nature in many countries, credibility problems may occur (Mahoney et al. 2013; Maroun 2020). Therefore, hiring a chartered accountant to provide an external review of the report's content may enhance a CSR report's credibility. Through implementation of CSR committees and CSOs, the company signals that stakeholders' CSR demands are included explicitly in the composition of the board of directors (Spence 1973). According to signalling theory, top management likes to inform its stakeholders about its CSR-related concepts and will increase its sustainability board expertise, as it leads to better accountability and a stronger connection between business and society. Thus, it can be assumed that the CSR committee and CSO will contribute to better CSR performance, especially in the long run, compared with a company without such a function, signalling more ethical attitudes among the board of directors (Baraibar-Diez and Odriozola 2019). In this context, we can assume that the transmitter (CSR committee and CSO) will use CSR-related communication instruments (e.g., a CSR report) to convey the firm's CSR strategy and resources to the receiver (stakeholders). 
To sum up, based on legitimacy theory, in combination with stakeholder theory, we can assume that CSR committees and CSOs will promote the decision to prepare and assure a CSR report on a voluntary basis. We expect that similar companies will conform to this by implementing such structures and practices to gain social acceptance. Thus, competing firms imitate specific CSR strategies (e.g., the implementation of CSR committees and CSOs) from other firms to enhance their reputation. Additionally, we conclude that CSR committees and CSOs will foster a company's CSR-related activities, leading to an increase in CSR performance. As some regulatory environments already have passed laws on mandatory CSR reporting for PIEs, e.g., European Union CSR Directive 2014 (Pizzi et al. 2020), this circumstance will increase the normative pressure on all organisations acting in the same area. These organisations will react towards these developments through implementation of institutionalised sustainability board expertise on a voluntary basis.

Thus, we neglected the risks of a symbolic use of institutionalised sustainabilityrelated board expertise in the implementation of our research framework and compared this assumption with the empirical results. Thus, it might be assumed that the CSR committee and CSO will promote a company's CSR-related outputs.

\subsubsection{Upper-echelons theory}

Regarding CSOs, we complemented our theoretical foundation with upper-echelons theory (Hambrick and Mason 1984), which assumes that powerful actors in an organisation essentially influence its outcomes. An organisation's resulting strategies and performance represent a reflection of its powerful actors' values and cognitive biases (Hambrick and Mason 1984). The powerful actors within an organisation normally are members of the top management team and, due to the complexity of companies' situations and corresponding strategic decisions, their behaviour may be characterised as bounded rational.

Regarding a specific situation, upper-echelons theory assumes that so-called 'upper-echelons characteristics' of top management reflect the situation that the respective organisation is facing (Hambrick and Mason 1984). Besides psychological factors, such as cognitive values, of particular relevance are observable characteristics, such as age, education, other career experiences (Hambrick and Mason 1984) and changing executive job demands (Hambrick 2007). These upper-echelon characteristics act as determinants of strategic choices and resulting organisational performance (Hambrick and Mason 1984).

As the top management team's composition is of crucial importance in achieving solid organisational outcomes (Carpenter et al. 2004), and classical board positions, such as CEOs or CFOs, might not be the appropriate to prepare CSR-oriented strategies (Waldman et al. 2006), a research shift to other top management members is necessary (Peters et al. 2019). As the CSO in particular fosters an entity's CSR-related activities as a member of top management, it can be assumed that the CSO in particular will engage in CSR reporting, illustrating the CSR strategy, which CSR targets the company has achieved and which CSR challenges remain. Furthermore, the CSO will support CSRA conducted by an independent third party, as this engagement may enhance the report's credibility and the company's underlying CSR 
Inputs

CSR outputs

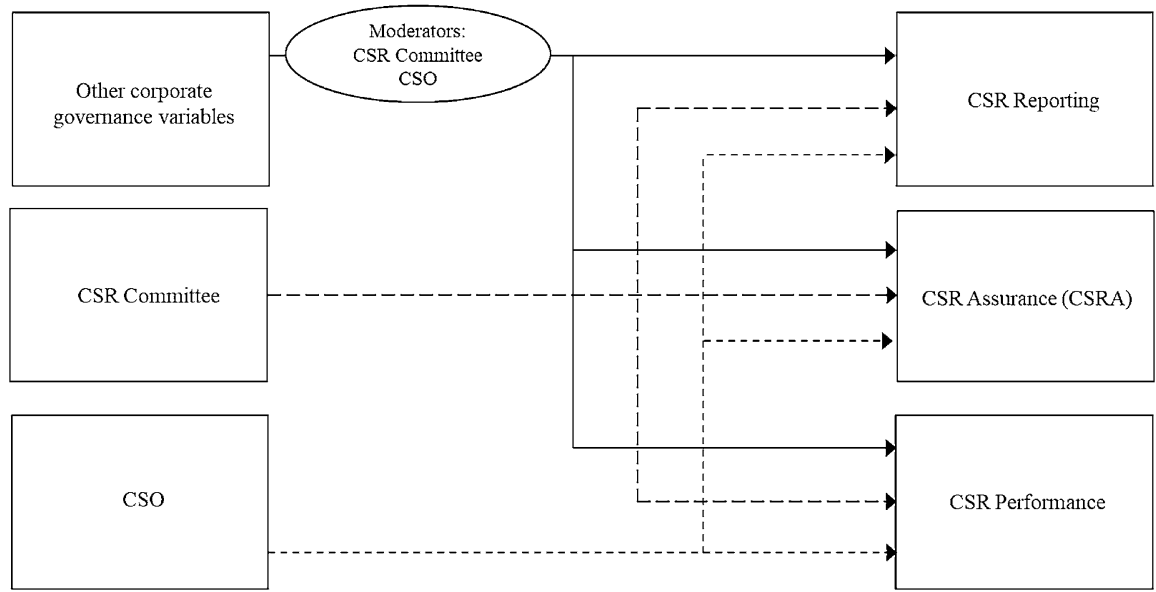

Fig. 1 Research framework

activities. As the CSO will engage in the achievement of CSR-related targets, it may be expected that the respective company's CSR performance will improve.

Based on upper-echelons theory, we conclude that a top management team containing a CSO with organisation-specific knowledge regarding CSR-related issues may solve CSR-related situations within an organisation more effectively than top management teams without a CSO. As a result, we conclude that the implementation of a CSO will promote CSR-related activities and outputs within the respective company, and will become more common in business practice. Based on an institutional approach, companies acting in the same branch will adopt these common practices and likewise implement the CSO position. Thus, upper-echelons theory represents a useful contribution to legitimacy and stakeholder theory.

Finally, our research question (RQ) is: Do CSR committees and CSOs impact CSR reporting, CSRA and CSR performance?

\subsection{Research framework}

Based on the described theoretical foundation and our deduction of three main CSR outputs, a research framework for the literature review was derived (Fig. 1). The research framework focusses on the impact of institutionalised sustainability board expertise via CSR committees and CSOs on three CSR-related activities: CSR reporting; CSRA; and CSR performance. Moreover, we are interested in moderator and mediator analyses performed in prior empirical studies on this topic. The implementation of CSR committees and CSOs can play a moderating or mediating role in the link between other corporate governance variables (e.g., board gender diversity) and CSR. Moreover, other corporate governance variables can moderate or mediate the link between CSOs and/or CSR committees and CSR. CSR measures, as dependent variables in our research framework, will be structured into three 
categories used mainly in prior conceptual and empirical research and which have been developed from our theories in the previous chapter:

1. CSR reporting,

2. CSRA,

3. CSR performance.

In line with other recommendations in CSR research (Malik 2015; Velte 2017), a clear separation between performance and reporting, and between total CSR and subcategories (e.g., environmental issues), is useful to our analysis. Stakeholders should be informed explicitly about a company's CSR activities. Most PIEs present separate CSR reports according to a variety of frameworks (e.g., Global Reporting Initiative standards), and shareholders and other stakeholder groups analyse these reports. According to our theoretical framework, firms like to gain legitimacy through their CSR reports. Moreover, over the years, financial figures, CSR reports and other information on firms are analysed by rating agencies to increase CSR ratings and scores as performance pillars. Our theoretical framework also indicates that firms intend to influence their CSR performance in a positive way. As CSR information may be connected with risks of greenwashing and information overload, it is crucial whether there will be positive stakeholder reactions. As stakeholders demand reliable and objective CSR reports, boards of directors will be active in engaging external parties to conduct CSRA. In line with our theoretical framework, we motivated the choice of these three CSR proxies with reference to the increased research activity on CSR reporting, CSRA and CSR performance (Velte and Stawinoga 2017a).

\section{Literature review methodology}

Empirical research on CSR committees and CSOs features heterogeneous methods, variables, data, theoretical approaches and regression models, leading to increased complexity (e.g., García Martín and Herrero 2019; Peters and Romi 2015; Peters et al. 2019). In light of this development, it is rather difficult to compare prior research results and provide a proper overview of this research topic. Due to their usefulness to business scholars, practitioners and regulators, literature reviews are gaining relevance in sustainable corporate governance research (e.g., Engert et al. 2016). Our systematic literature review is structured in line with established procedures (Denyer et al. 2008; Denyer and Tranfield 2009). First, as our research objective, we address the CSR consequences of CSR committees and CSOs (presence and composition). Our key research questions are as follows:

1. Do CSR committees and CSOs influence CSR outputs?

2. Which moderators or mediators influence the CSR committee- and CSO-CSR link? 
3. Do CSR committees and CSOs moderate or mediate the link between other corporate governance variables and CSR outputs?

We note major limitations and gaps in prior research and derive useful research recommendations from a content, methodological and theoretical perspective.

Second, we analyse the key theories within the cited studies, stress the different proxies used in prior research and develop a research framework.

Third, we use several international databases for our sample of studies: Web of Science; Google Scholar; Social Science Research Network (SSRN); EBSCO; and Science Direct. To identify relevant papers, we use the following keywords: 'chief sustainability officer(s)'; 'CSO'; 'chief environmental officer(s)'; 'chief corporate social responsibility officer(s)'; 'CSR committee(s)'; 'corporate social responsibility committee(s)'; 'environmental committee(s)'; 'social committee(s)'; 'sustainability committee(s)'; and other synonyms ('ethics committee', 'sustainable development committee', 'health and safety committee', 'chief ethics officer', 'chief social officer', 'chief CSR officer', 'environmental team', 'social team', 'CSR team', 'CSR department', 'environmental department' and 'social department').

Fourth, we discuss exclusion criteria. Due to our topic's global importance, restricting search results to a specific time period or region was not necessary. To discuss CSR-related effects from CSR committees and CSOs, we focus on empirical-quantitative studies. We are aware that some researchers use an empiricalqualitative design (Strand 2013, 2014) or analyse specific determinants of CSO and CSR committee implementation (Eberhardt-Toth et al. 2019; Gennari 2019; Gennari and Salvioni 2019) or financial outputs (Jaggi et al. 2018a; Schulz 2017; Wiengarten et al. 2017). However, these research topics are of minor relevance so far. In our literature review, we explicitly focus on the impact from CSR committees and CSOs on CSR outputs and not on financial effects as CSR-related board experts' key motivation should be to promote CSR issues. Thus, in our literature review, we do not concentrate on the 'business case' perspective of institutionalised sustainability-related board expertise. While CSR committees and CSOs also might influence financial performance, prior research mainly relates to CSR outputs. To guarantee this literature review's quality, we only included articles published in peer-reviewed English-language scientific journals. Thus, published books, book chapters and current working papers (e.g., those published on SSRN) are not included, in line with other literature reviews on CSR and corporate governance (e.g., Fifka 2012; Hahn and Kühnen 2013; Jain and Jamali 2016). The included studies mainly use secondary (archival) data to gather independent or dependent moderators or mediators and/ or control variables for the statistical models. Moreover, some researchers also gain primary data via content analysis of sustainability and corporate governance reports, interviews or surveys per mixed-methods design.

Fifth, a precursory analysis of the studies was carried out. Our precursory sample of studies comprised 76 articles. After scanning the articles' titles and abstracts, we excluded 14 articles that lacked empirical-quantitative research methods, six that lacked CSR outputs and eight that were not published in English-language peerreviewed journals, leaving a final sample of 48 studies in our literature review. 
Sixth, vote-counting methodology (Light and Smith 1971) was used to code relevant empirical studies with regard to the selected (sub-)constructs and our research framework. We evaluated the significant results from regression analyses within the empirical studies. A positive (negative) significant relationship between CSR committee, CSO and CSR outputs was coded as $1(-1)$, and an insignificant link between these variables was coded as 0 . We then counted the number of (in)significant results distinguished between CSR committees and CSOs, as well as their impact on CSR performance, CSR reporting and CSRA. The (in)significant results and their indicators $(+,-, \pm)$ are provided in Table 2 .

We are aware of the limitations of vote counting in literature reviews (Combs et al. 2011). Vote counting is a limited method for synthesising evidence from multiple evaluations, which merely involves comparing the number of significances. The vote counting method does not take sample size or effect size into account. These restrictions in vote counting and narrative literature reviews might be overcome by the use of quantitative meta-analysis (Combs et al. 2011). Although meta-analyses are not very common in management control and corporate governance research, we found that an increasing number have been published over the years (Byron and Post 2016; Endrikat et al. 2020; Khlif et al. 2015; Khlif and Chalmers 2015). As there are very conflicting results from empirical-quantitative studies in sustainable corporate governance research, meta-analyses statistically summarise existing research and increase the quality of results compared with literature reviews. Furthermore, meta-analyses can include relevant moderator analysis across multiple studies (Khlif et al. 2015; Khlif and Chalmers 2015). If a reasonable number of studies exists on our research topic, we suggest performing quantitative meta-analyses of the impact from CSR committees and CSOs on CSR-related and/or financial outputs.

Nevertheless, a meta-analysis that focusses on the link between CSR committees, CSOs and CSR outputs is not useful yet, considering the low number of extant empirical-quantitative studies on that topic, especially on CSOs. Moreover, our three categories of CSR outputs are too heterogeneous to conduct an overall metaanalysis. We propose conducting future meta-analyses on this link if they represent a satisfying number of studies with regard to the international context.

\section{Findings from the literature review}

\subsection{Content analysis on included studies}

Table 2 provides a content analysis of the reviewed studies. We focussed on the basic characteristics of our sample of included literature, including time of publication, country, journal of publication, selection of independent variables (CSR committee and CSO) and dependent variables, such as CSR-related effects, theoretical frameworks and the methodology used in empirical-quantitative research. The first empirical-quantitative study was performed in 2010, and the field has grown considerably over the past two years (Fig. 2). Both cross-country studies (18) and analyses for the US-American capital market (12) were conducted (Fig. 2). Cross-country studies are relevant, as the governance environment is 


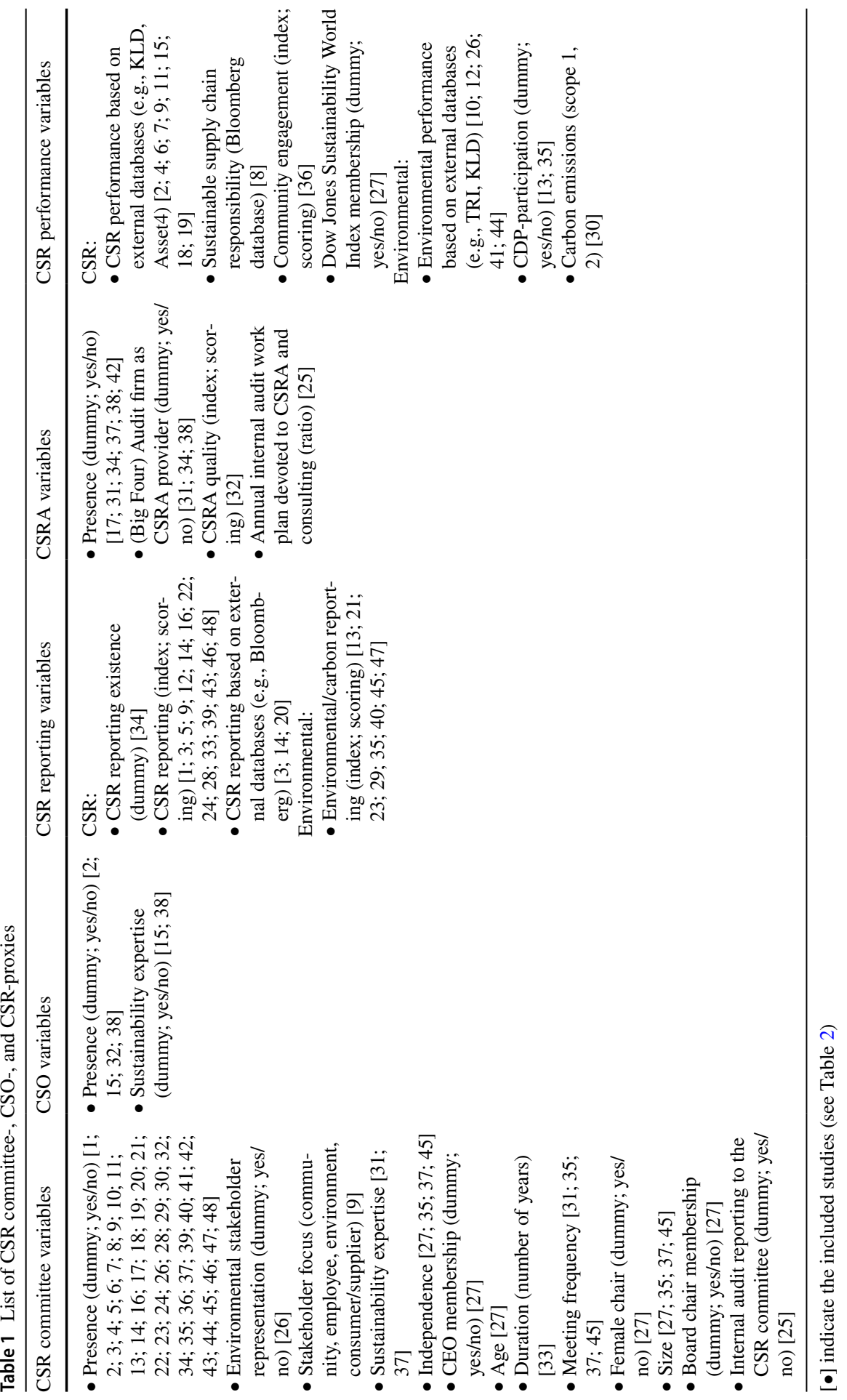




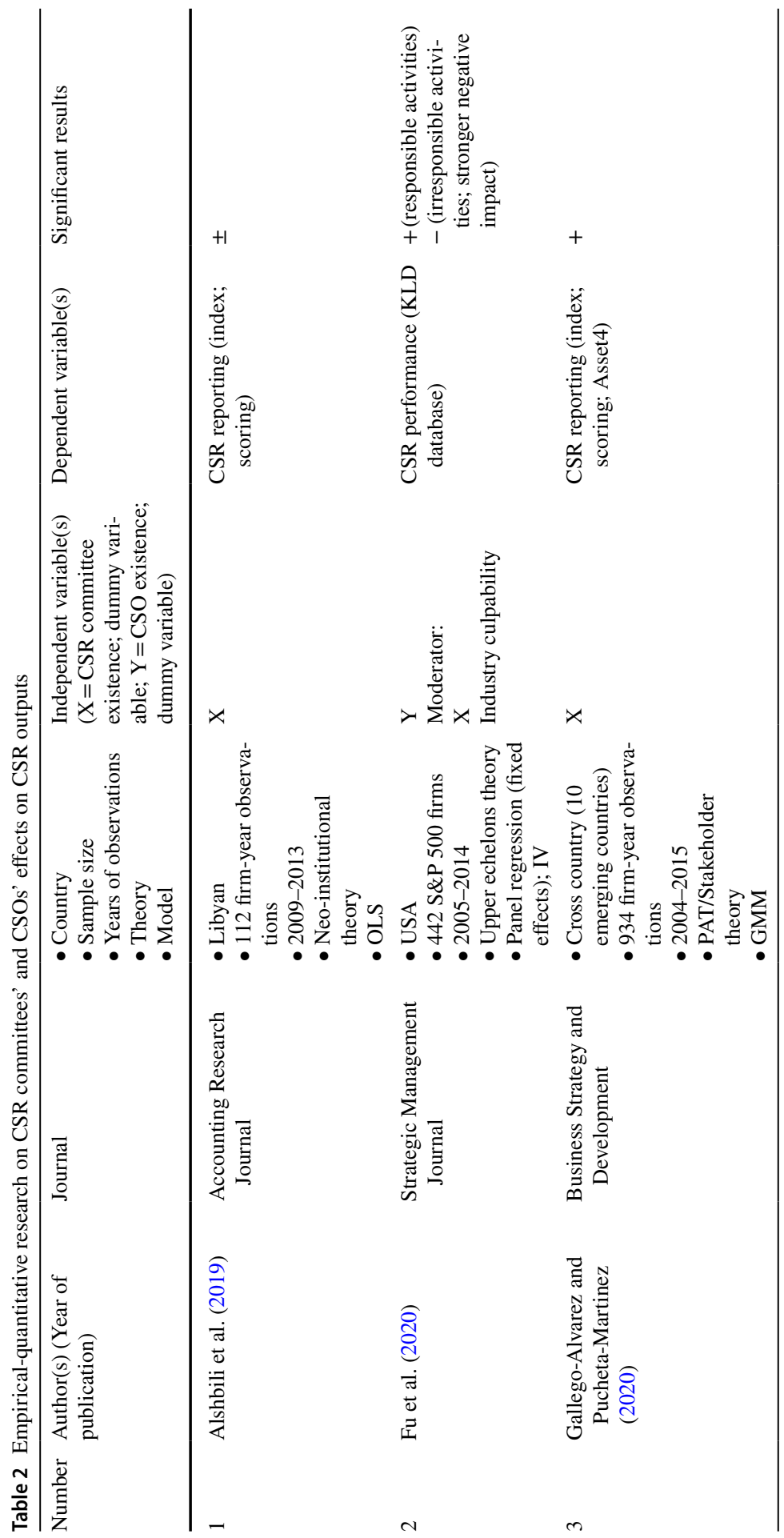




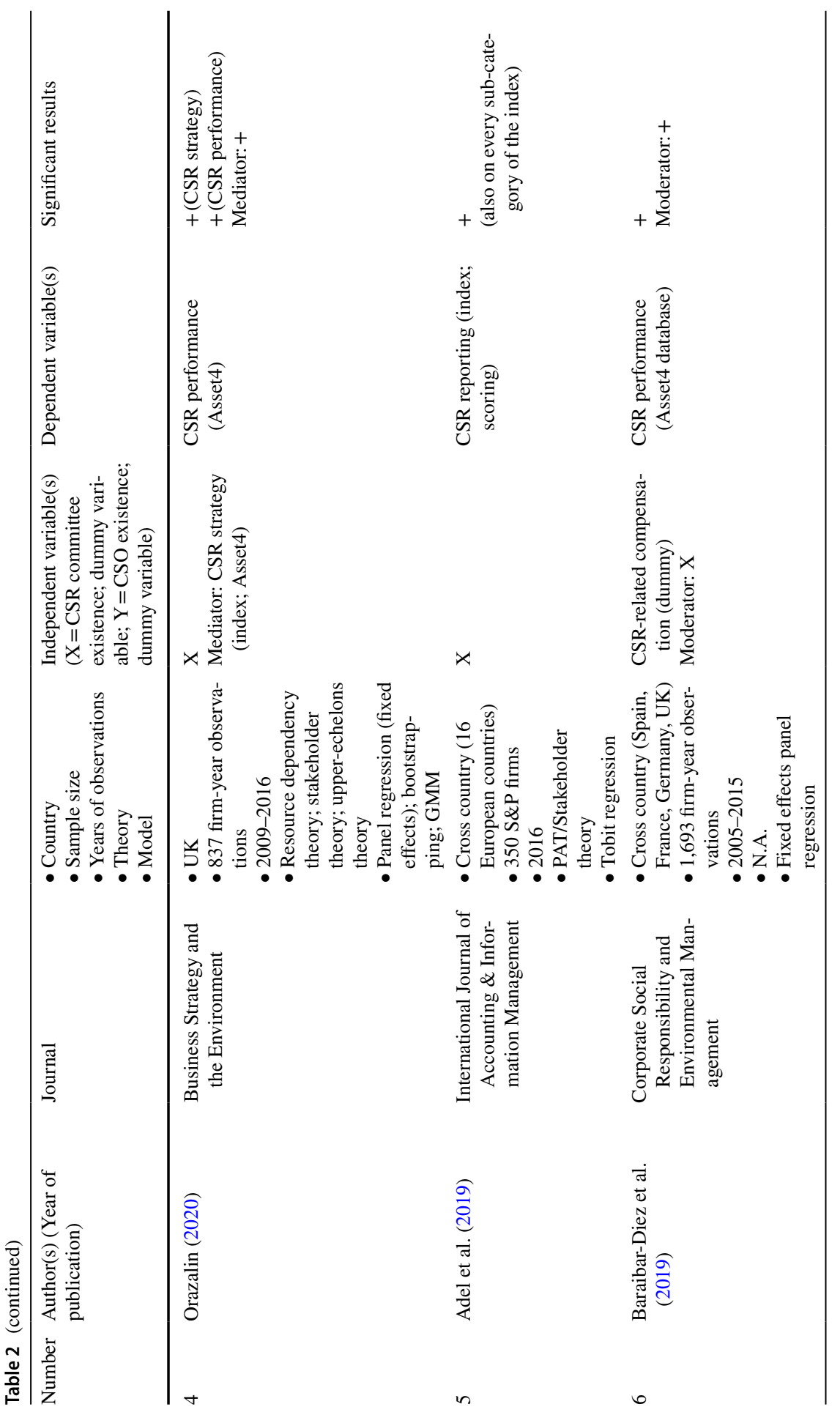




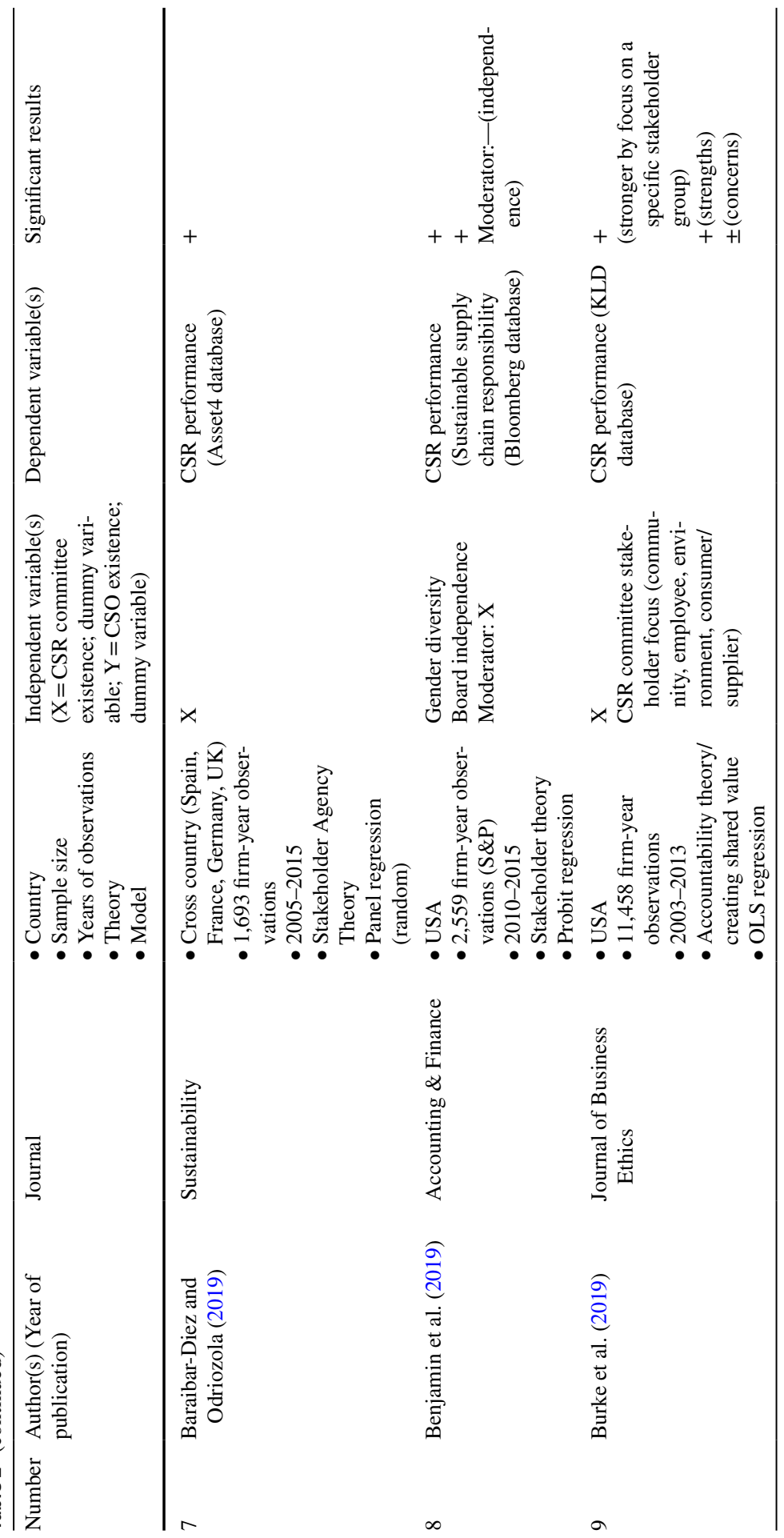




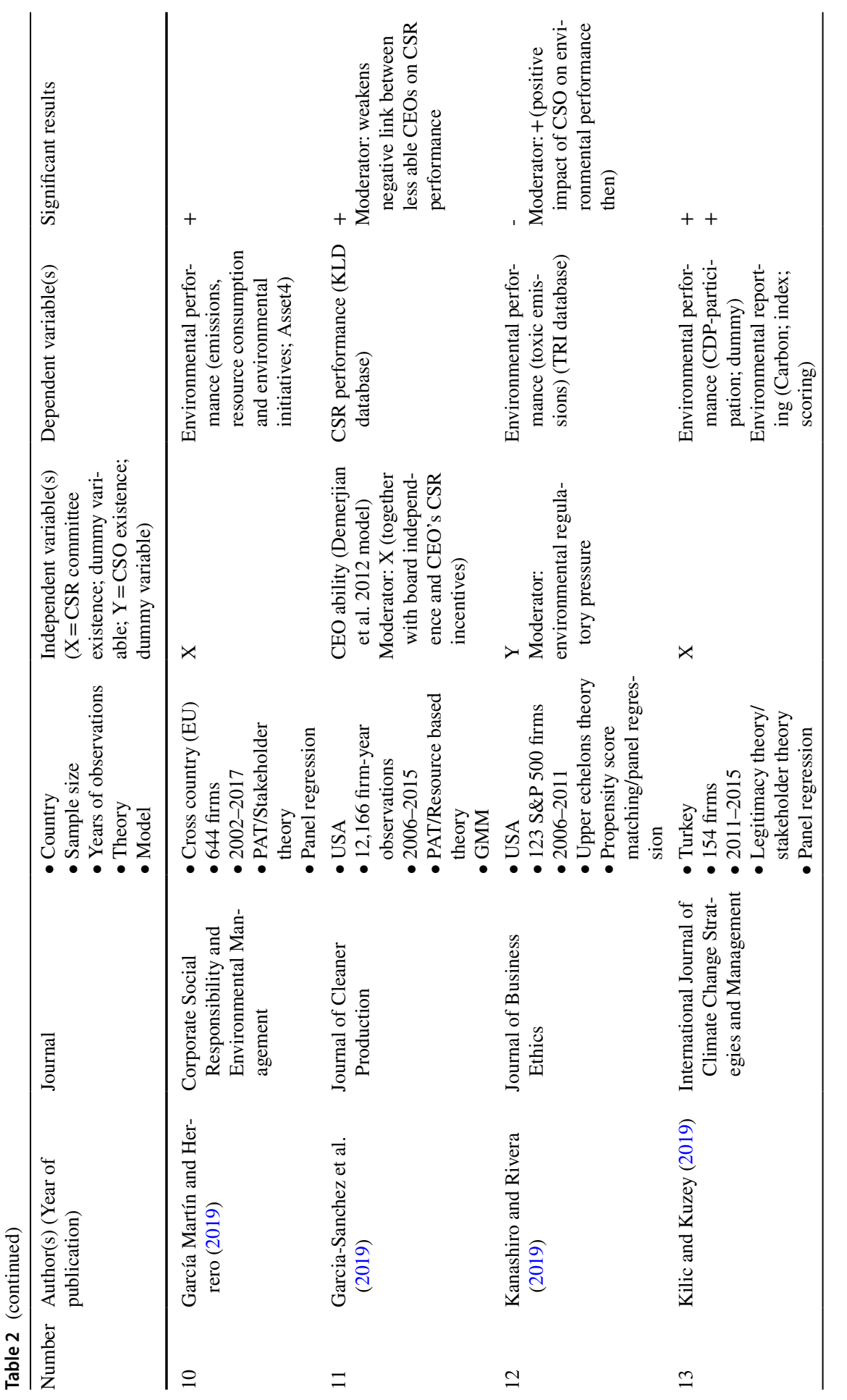




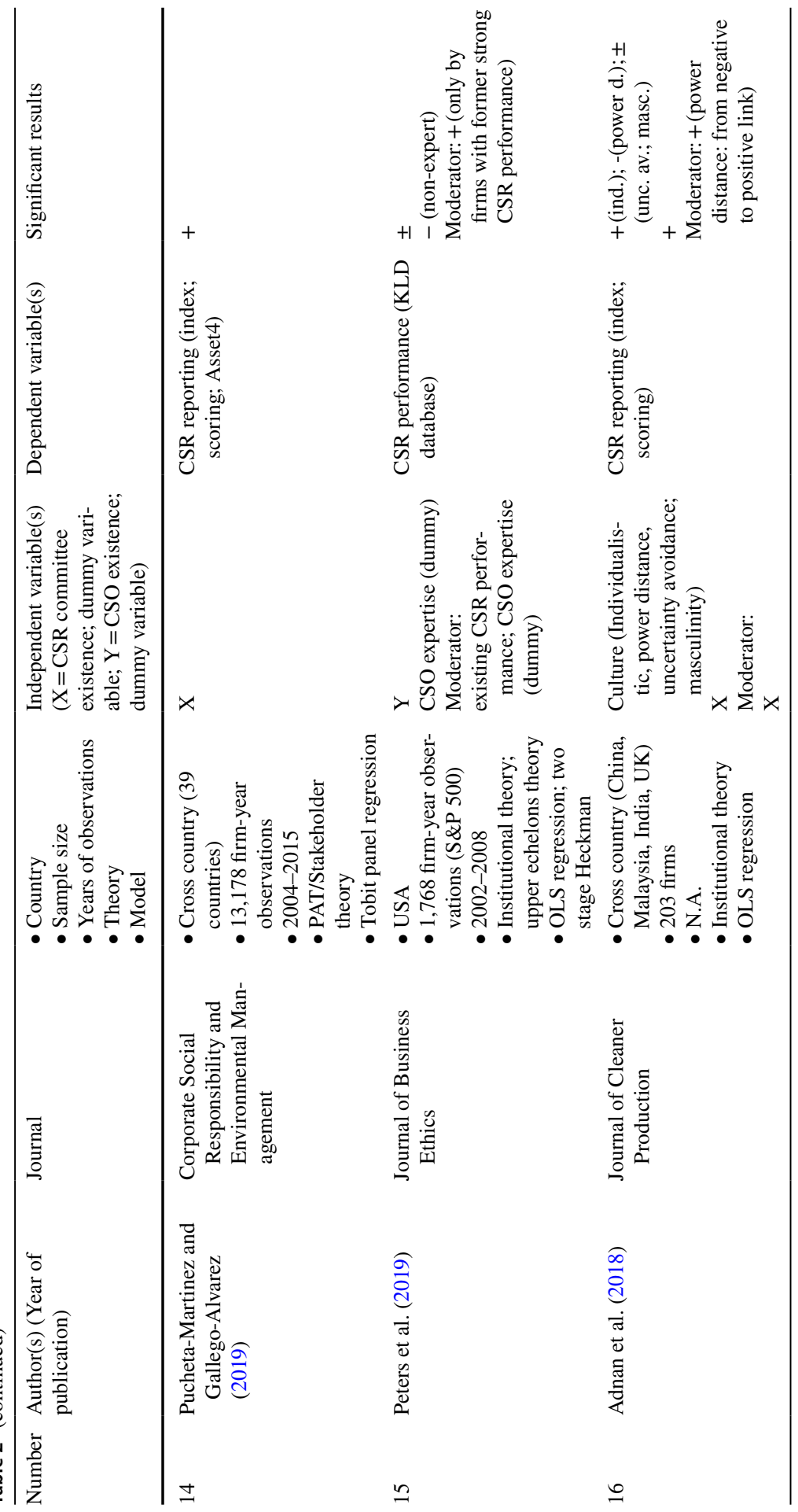




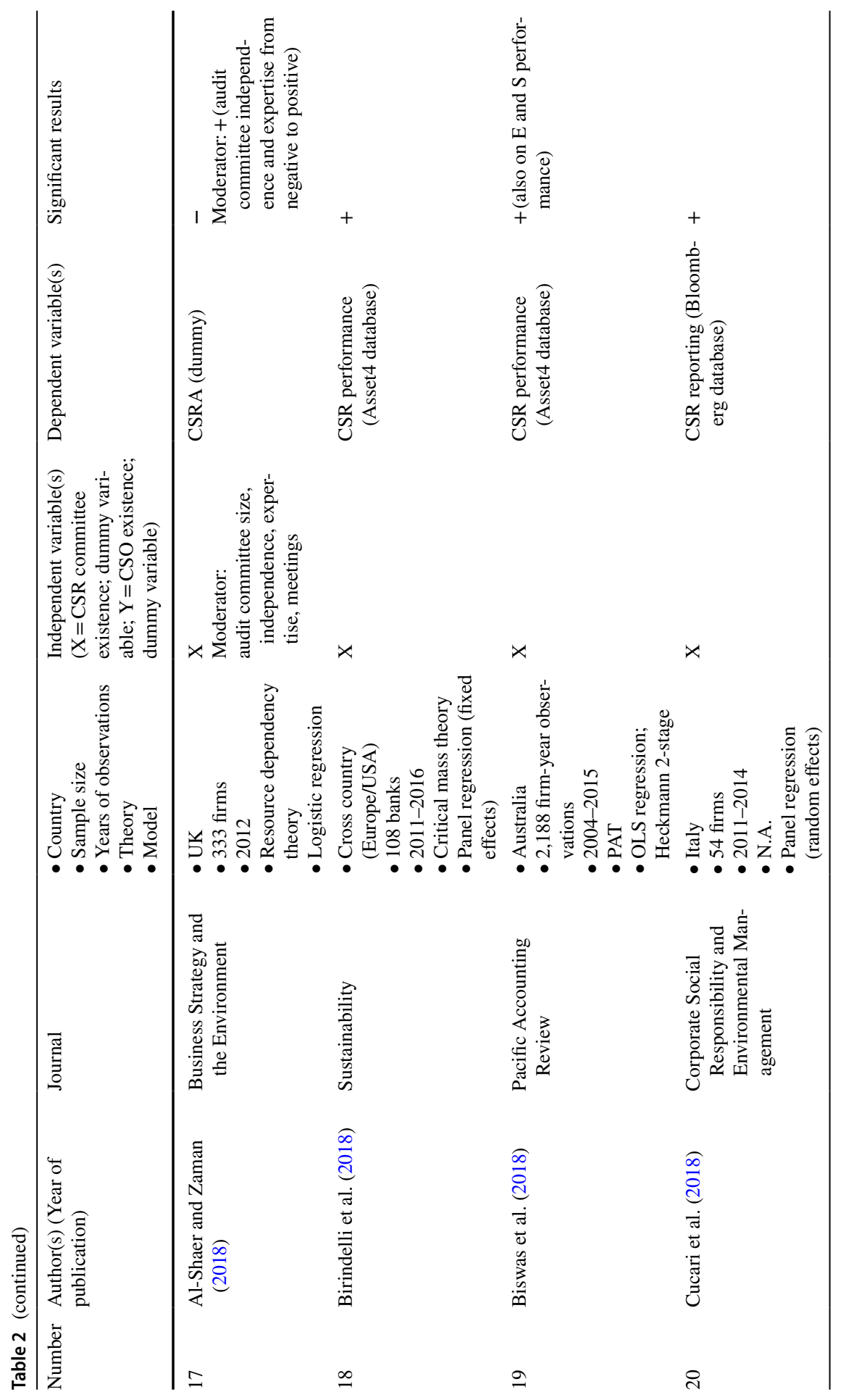



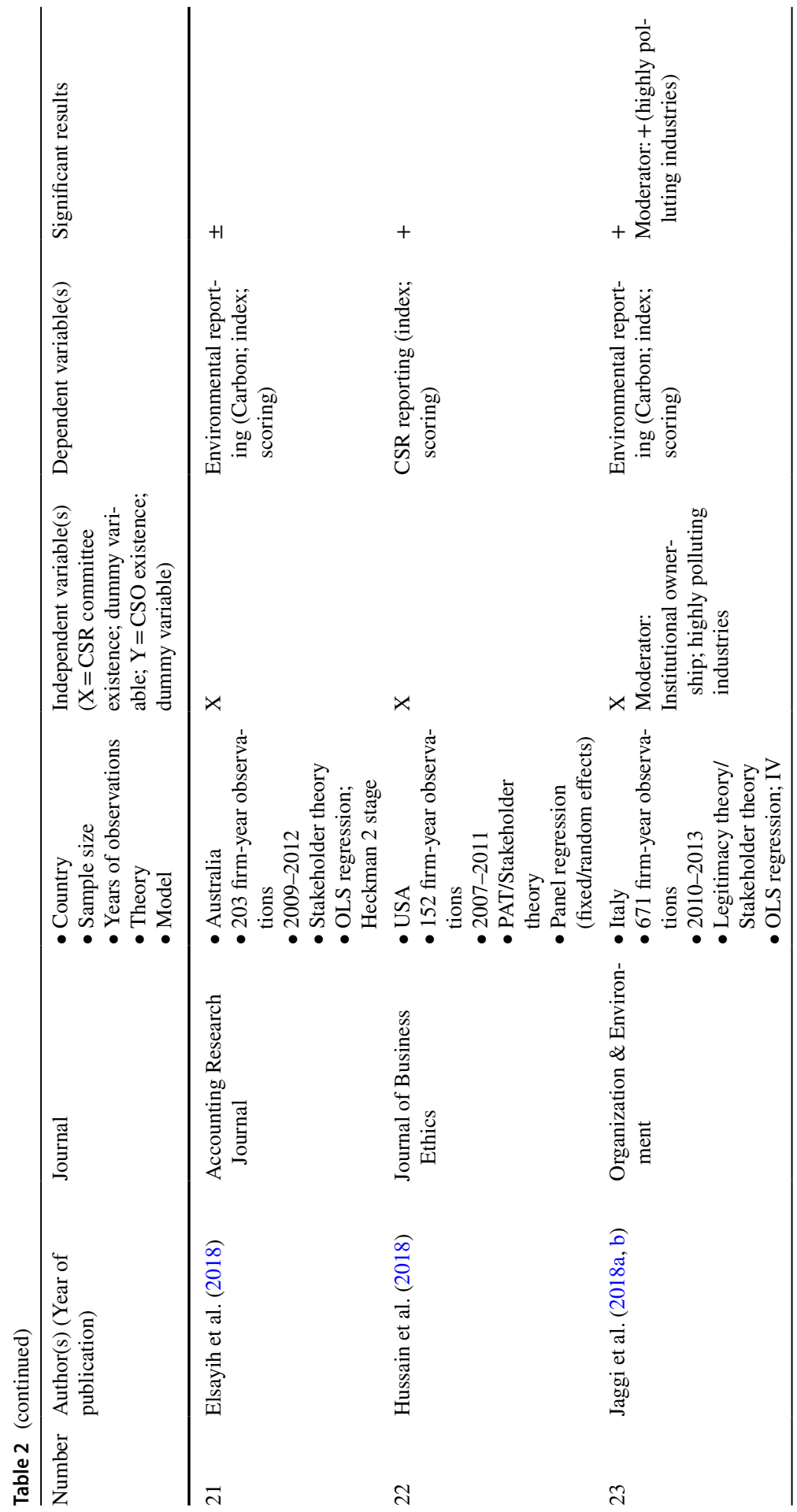


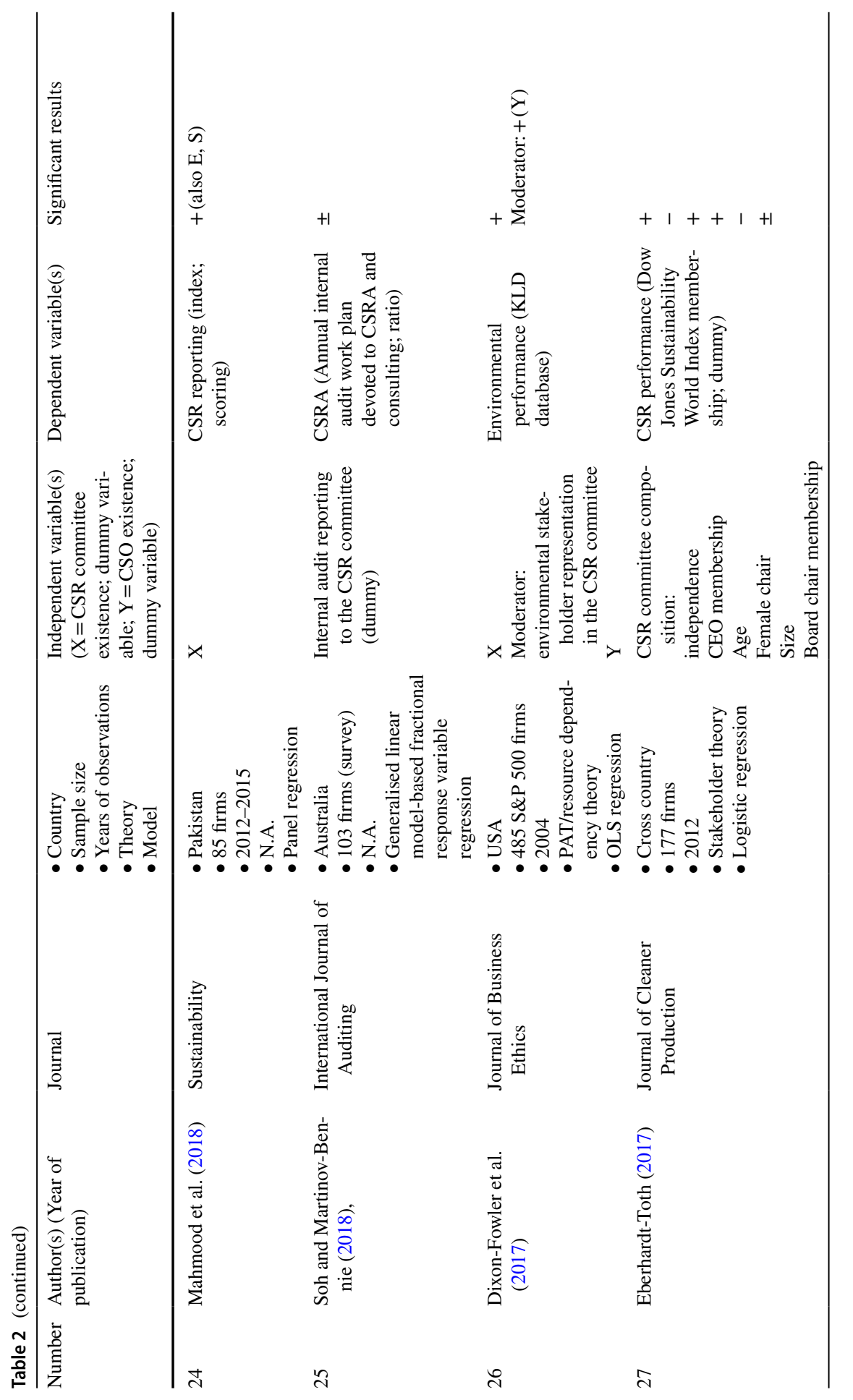



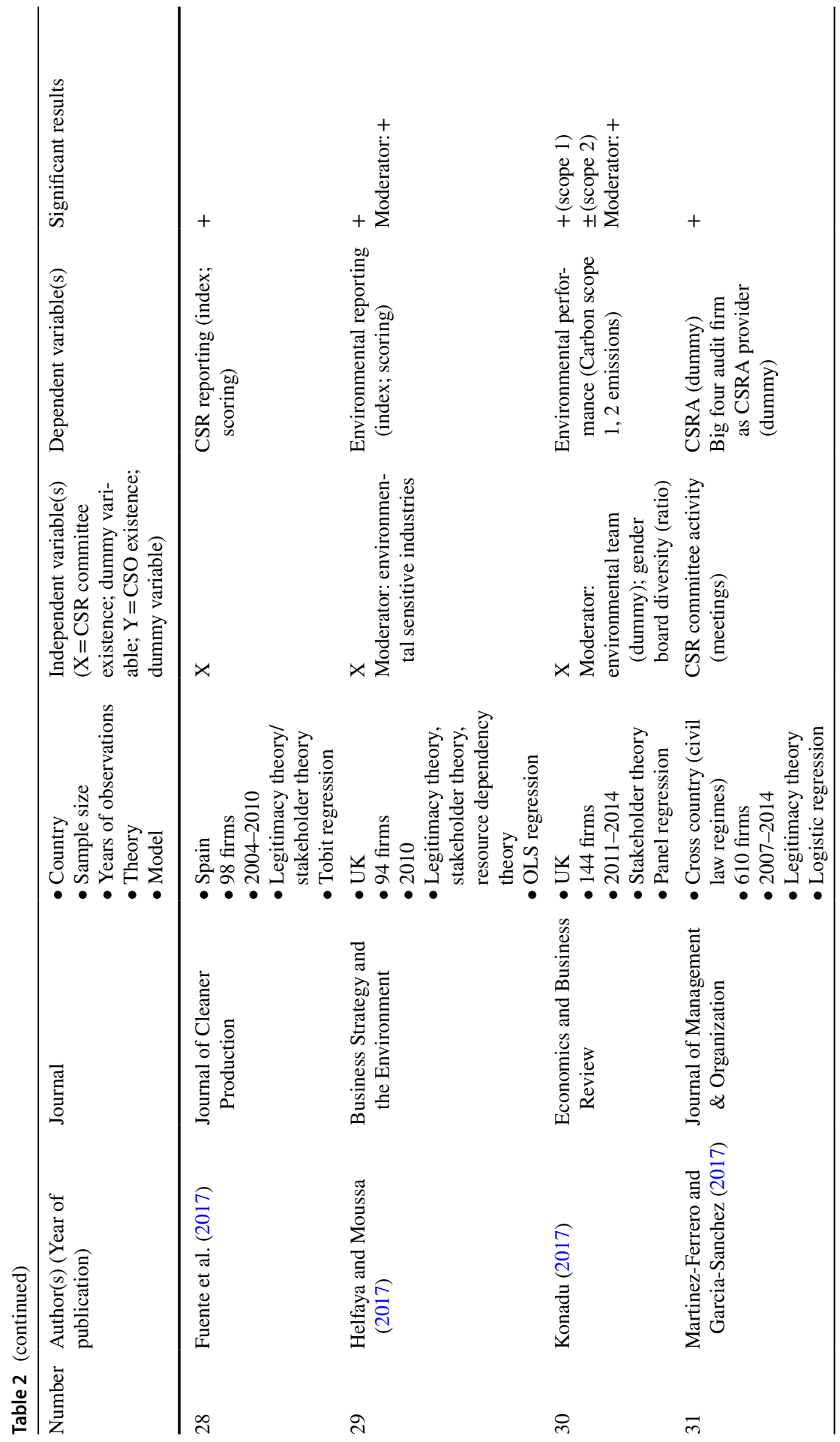


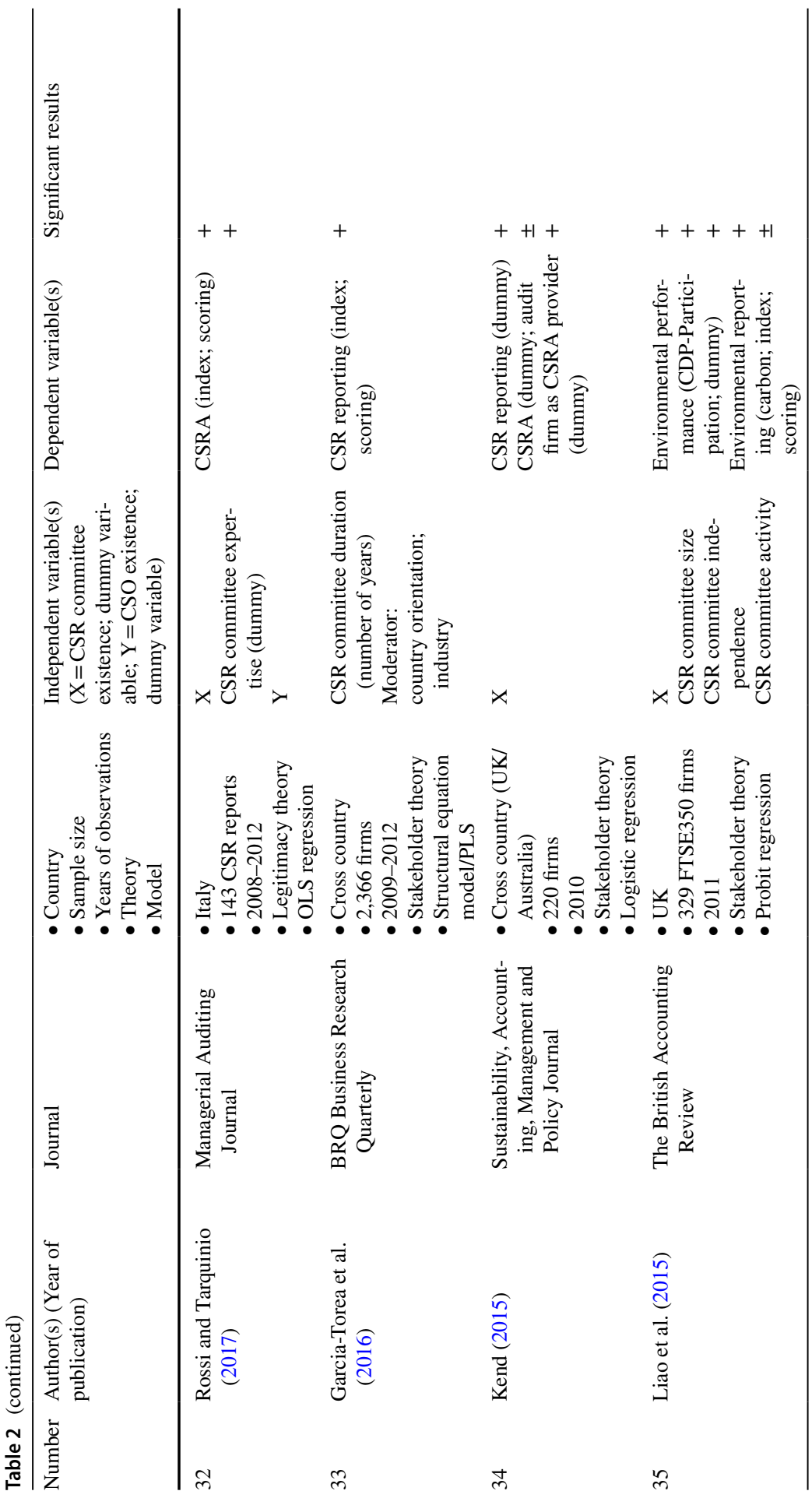




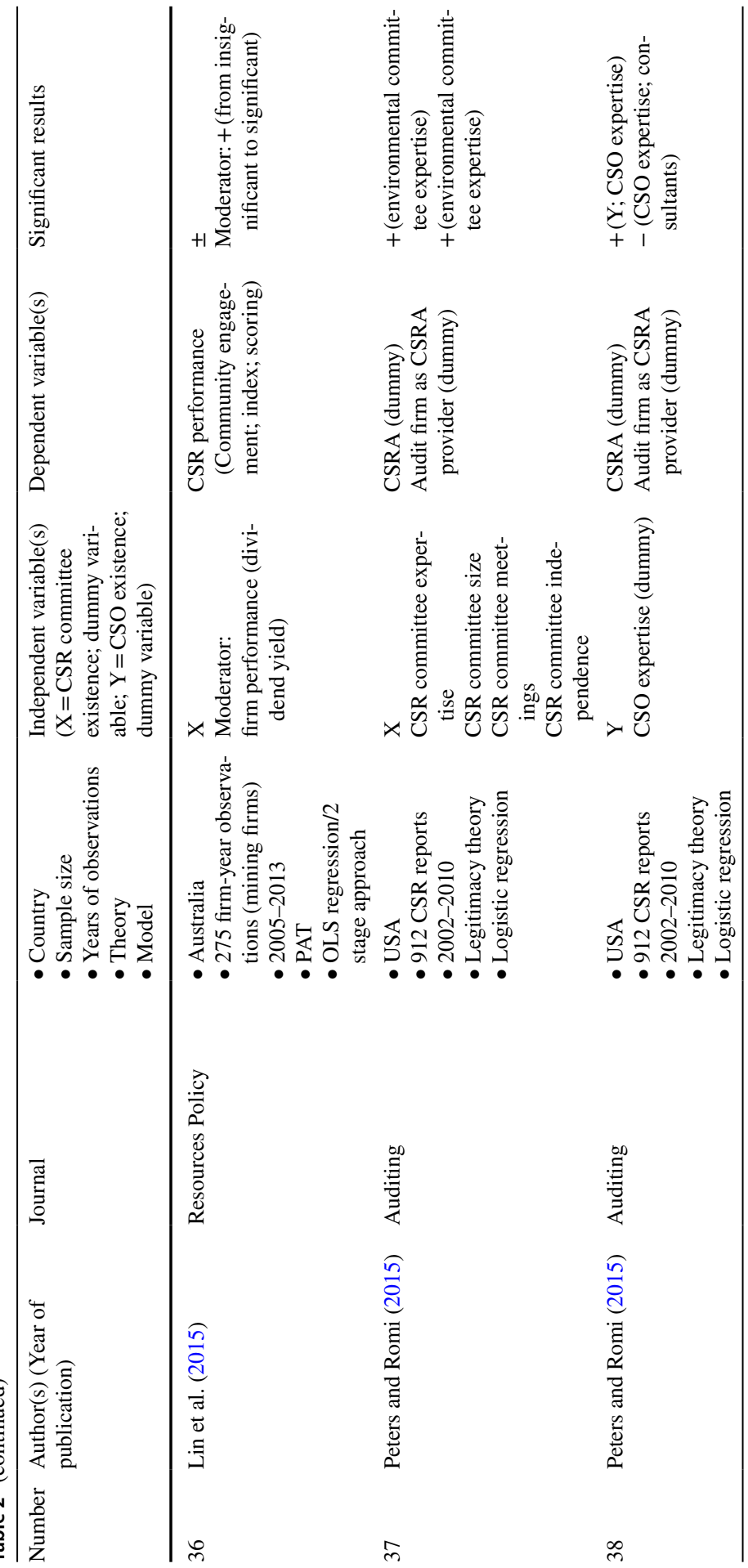




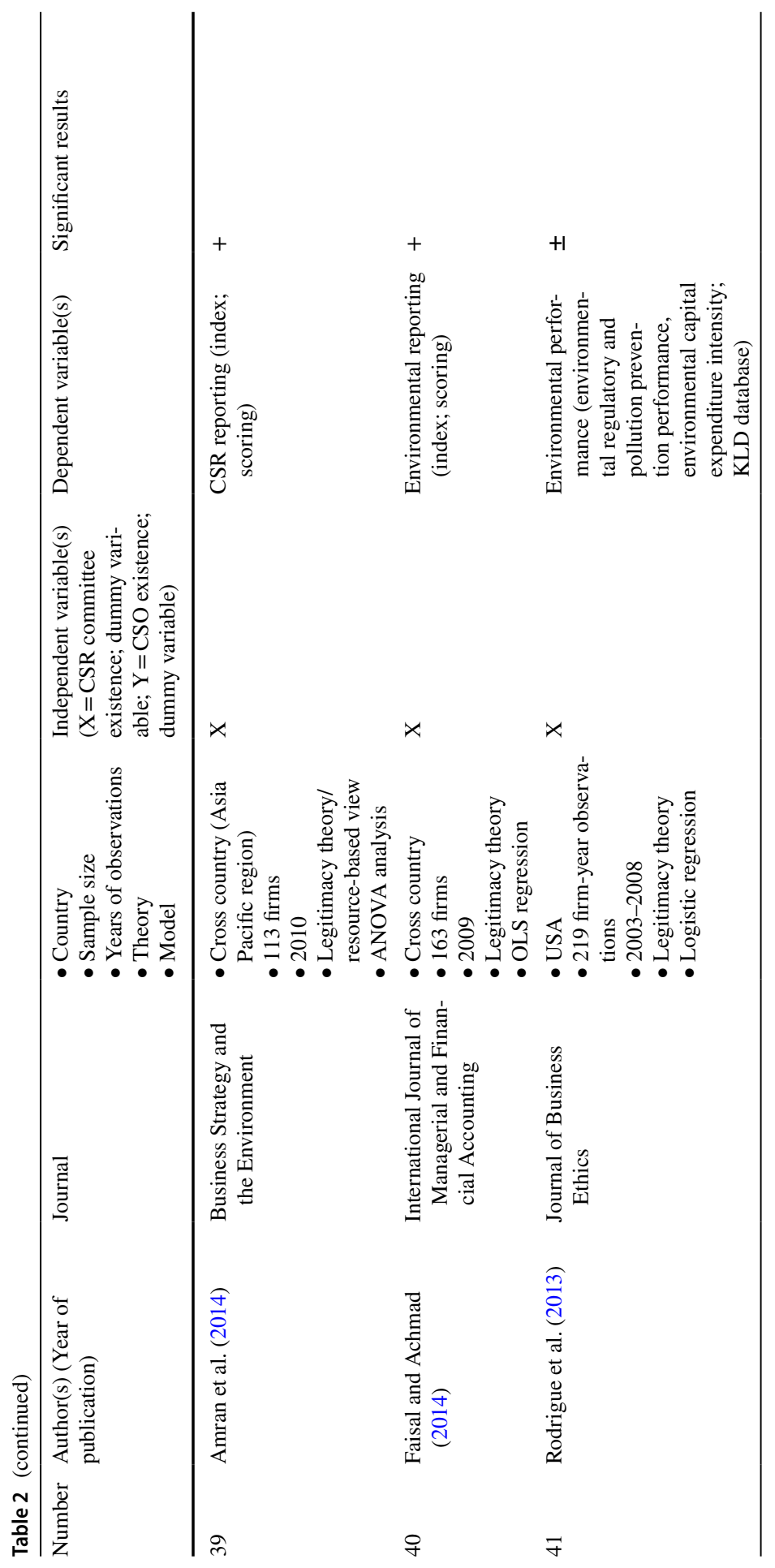




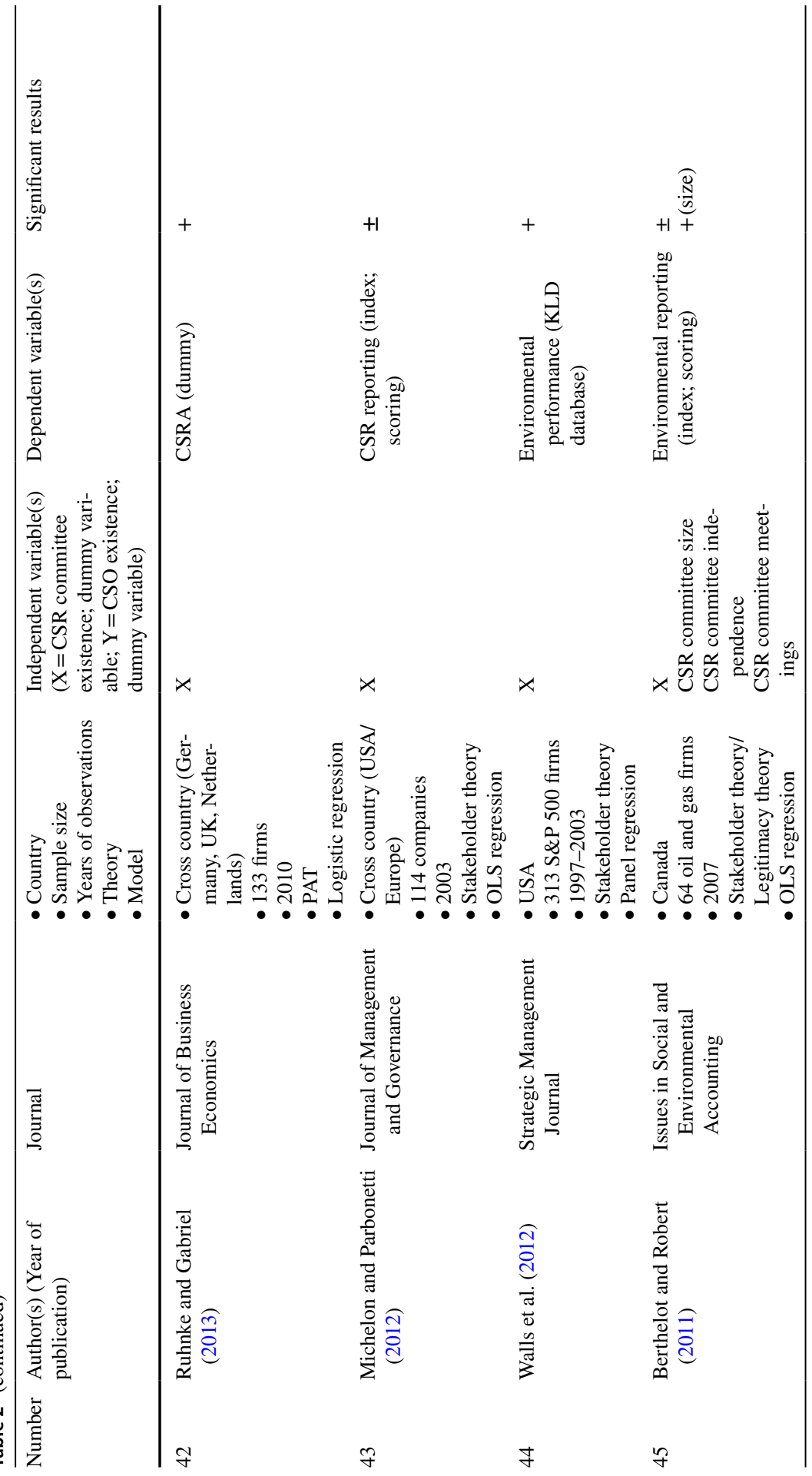




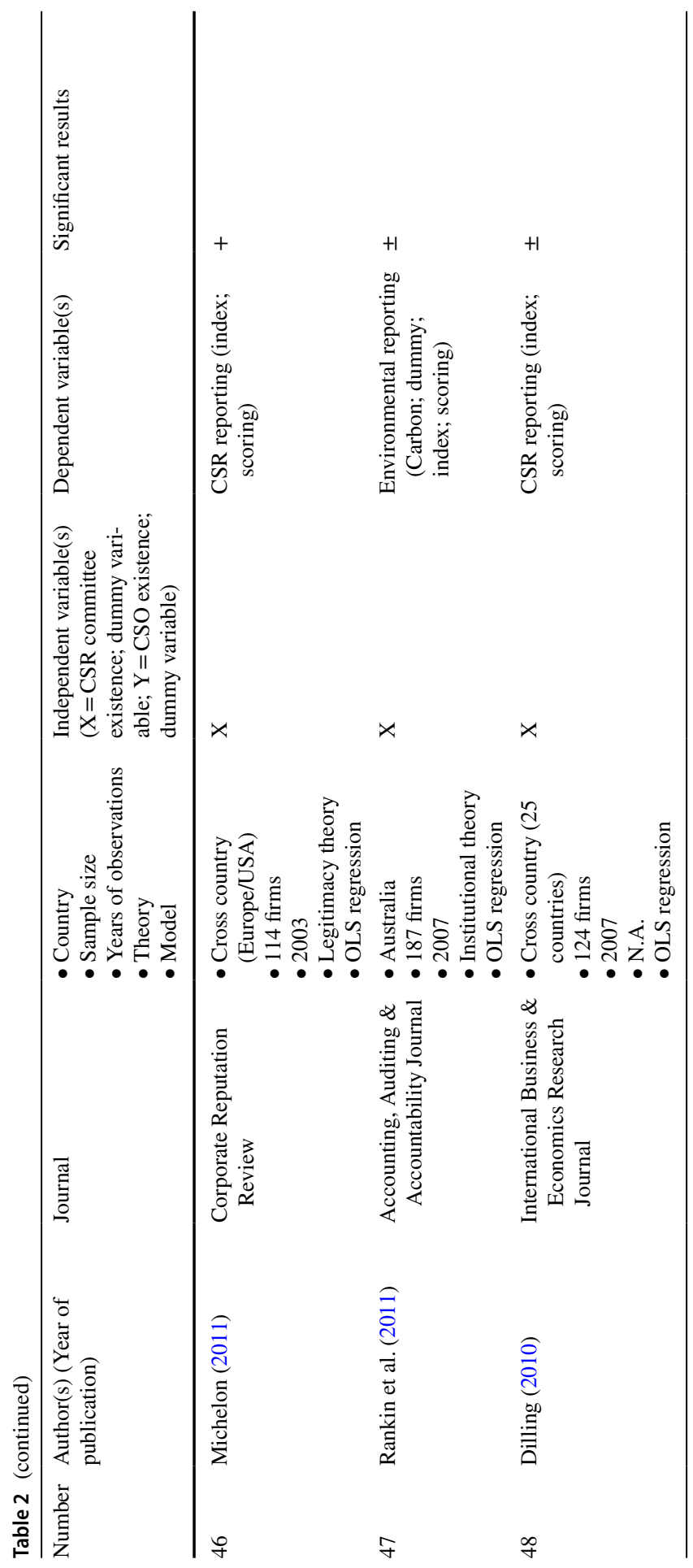




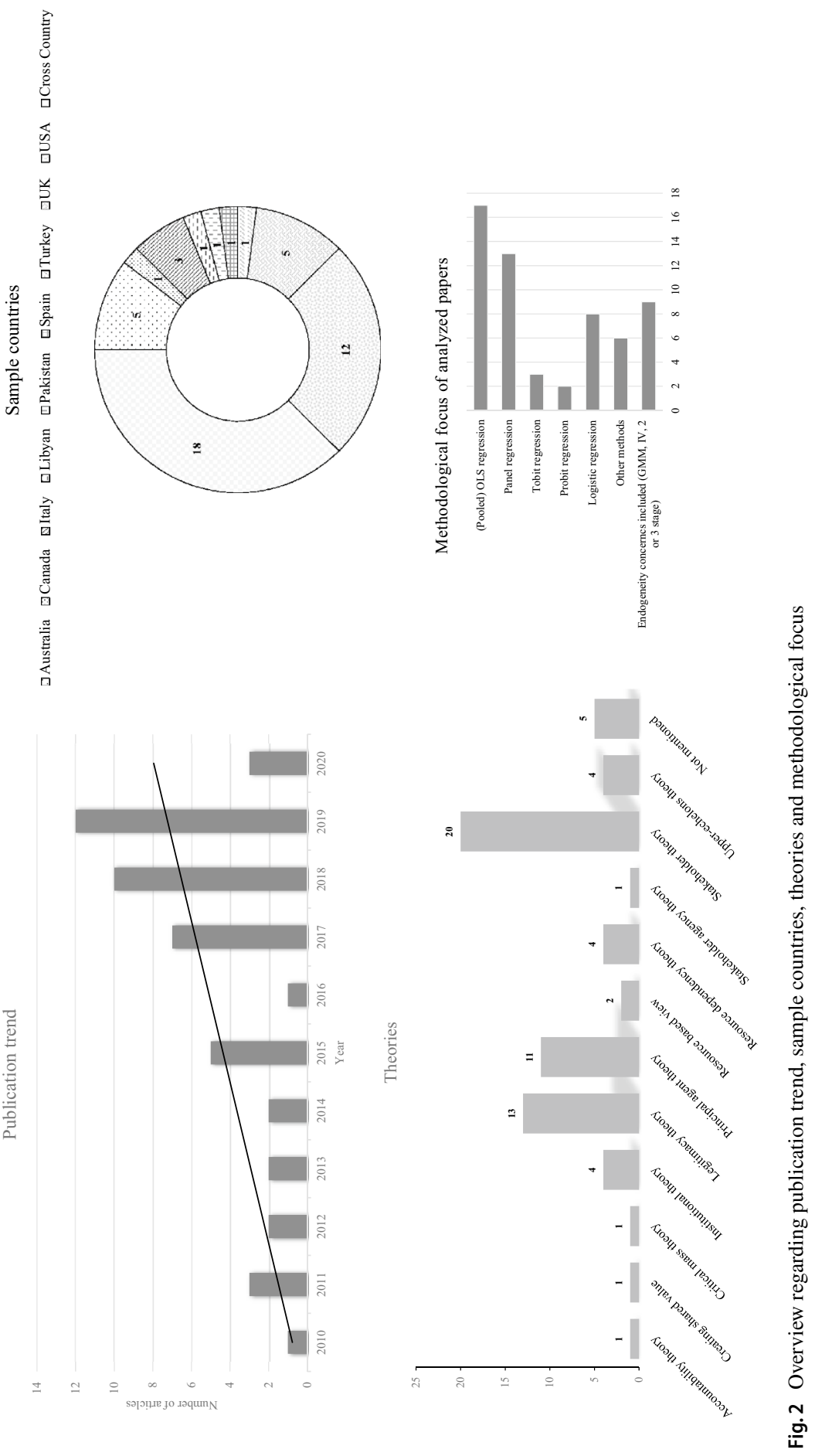


rather heterogeneous (e.g., shareholder rights) and should be included in research designs. The US-American setting seems to be an attractive research objective, as empirical research on top management and board committee composition has a long tradition, and high-ranking journals prefer listed US firms with regard to increased database quality. Most studies have been published in business ethics and sustainability journals (Fig. 3), especially the Journal of Business Ethics (6), Business Strategy and the Environment (4), Corporate Social Responsibility and Environmental Management (4) and the Journal of Cleaner Production (4). Prior research mainly focussed on CSR committees (41) compared with CSOs (5). The most relevant CSR effects are CSR reporting (22) and CSR performance (19). Research on CSRA (9) as a dependent variable is of little interest so far. We also noted a variety of different theories on recent empirical research on this topic. Stakeholder theory (20), legitimacy theory (13) and classical principal agent theory (11) are the most common theoretical foundations, whereas a few papers do not explicitly rely on a specific theory (5) (Fig. 2). Upper-echelons theory mostly is used in CSO studies. As CSR committee and CSO adoption is voluntary from an international perspective, most researchers use a dummy variable (presence $=1$, otherwise 0). While Fig. 2 indicates that (pooled) Ordinary Least Squares (OLS) (17) and panel regressions (13) are most common, voluntary adoption of CSR committees and CSOs is linked with a self-selection (sample) bias. To address these concerns, propensity score matching (Rosenbaum and Rubin, 1983; Shipman et al. 2017), in combination with a difference-in-differences approach, is recommended in the literature. Only one study in our literature review uses propensity score matching (Kanashiro and Rivera 2019). As some studies use a dummy variable (e.g., CSRA, CDP participation), a probit or logistic regression was conducted. As the link between corporate governance variables and CSR is characterised by endogeneity concerns, the literature proposes a generalised method of moments (GMM), instrumental variables or two/three stage approaches (Wintoki et al. 2012). In our included studies, nine researchers explicitly address endogeneity in their designs.

Besides literature reviews, some researchers also conducted meta-analyses on the link between corporate governance variables and CSR measures. Byron and Post (2016) focussed on board gender diversity's impact on CSR, while Ortas et al. (2017) concentrated on the influence of board independence on CSR. Majumder et al. (2017) and Velte (2019a, b) included several corporate governance variables and analysed their impact on CSR performance and reporting. In line with prior literature reviews, CSR committees and CSOs were not included in the meta-analyses. Regarding the restricted number of studies and the low number of cross-country studies, a meta-analysis on this topic would not be useful yet. In a recent meta-analysis, Endrikat et al. (2020) analysed the link between several board composition variables (board size, board independence, gender diversity and CEO duality) and CSR, and included the implementation of CSR committees as a mediator. Thus, in light of increased research and practical and regulatory relevance, our literature review on the link between institutionalised sustainability board expertise via CSR committees and CSOs and CSR effects makes a useful contribution to present research on sustainable corporate governance. 


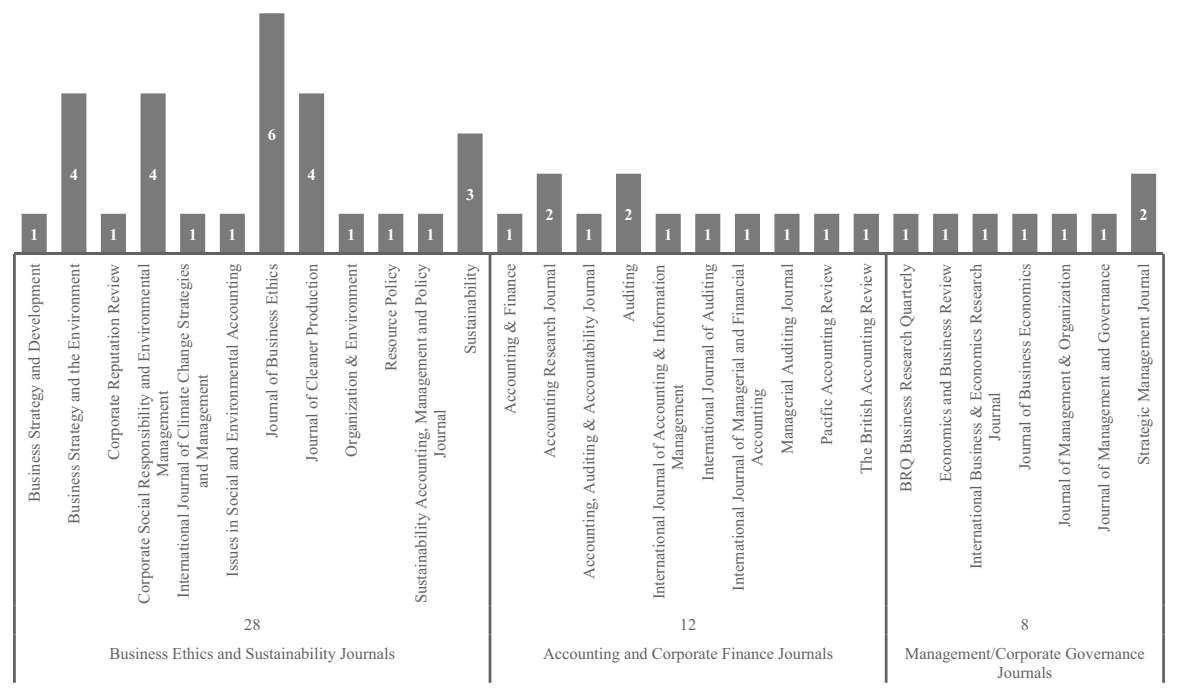

Fig. 3 Research field of publication medium

Table 1 presents the main proxies that have been used as CSR committee and CSO variables and CSR measures. As previously noted, both CSR committee and CSO adoption are approximated mainly by a dummy variable $(1=$ yes, $0=$ no $)$ because their implementation is voluntary from an international perspective. More detailed analyses of CSO characteristics and CSR committee composition (e.g., social and environmental expertise on the CSR committee) are not common yet. In the next chapter, we differentiate our analysis between 1) CSR reporting, 2) CSRA and 3) CSR performance. If the studies relied on CSR subgroups (e.g., environmental issues), we differentiate these results from overall CSR studies. In practice, CSR reporting and CSR assurance often are classified as subcategories of CSR performance, especially due to the use of external databases (mainly MSCI/formerly Kinder, Lyndenberg and Domini (KLD), Asset4 or Bloomberg). Thus, a successful CSR management system should promote CSR reporting, CSRA and CSR performance. In total, CSR committees, CSO variables and CSR outputs are connected with a heterogeneity of included proxies in prior research. Thus, comparability within the included studies may be limited partially.

In line with the heterogeneous use of institutionalised sustainability-related board expertise and CSR outputs, we identified inconclusive results on the impact from CSR committees and CSOs on CSR reporting, performance and assurance. Based on a theoretical framework, we concluded that CSR committees and CSOs will impact CSR outputs significantly. If managers' motivation is intrinsic and relies on stakeholder accountability perspective ('substantive' CSR strategies), a positive impact on CSR outputs should be realistic. If managers' motivation mainly is extrinsic and relates to the business case perspective ('symbolic' CSR strategies), 
we conclude that an insignificant, or even negative, effect on CSR outputs exists. To sum up, using a combination of legitimacy theory, stakeholder theory and upperechelons theory, we conclude that CSOs and CSR committees will lead to better CSR performance, CSRA and CSR reporting.

\subsection{CSR committees' impact on CSR reporting}

Most of our included studies in this literature review focussed on CSR committees' impact on CSR reporting or environmental reporting (22). However, no CSO study has been conducted yet. Most found a positive impact from CSR committees on CSR reporting, using cross-country samples (Adel et al. 2019; Amran et al. 2014; Gallego-Alvarez and Pucheta-Martinez 2020; Kend 2015; Michelon 2011; PuchetaMartinez and Gallego-Alvarez 2019) and different countries: Italy (Cucari et al. 2018; Rossi and Tarquinio 2017); the US (Hussain et al. 2018); Pakistan (Mahmood et al. 2018); and Spain (Fuente et al. 2017). Moreover, CSR committee expertise (Rossi and Tarquinio 2017) and CSR committee duration (Garcia-Torea et al. 2016) were related positively to CSR reporting. Thus, in line with legitimacy theory and stakeholder theory, there are indications that CSR committees are not used as a symbolic management tool, yet substantially increase CSR reporting quality.

With reference to environmental reporting, there are also indications of a positive impact from CSR committees, according to cross-country studies (Faisal and Achmad 2014) in Turkey (Kilic and Kuzey 2019), Italy (Jaggi et al. 2018a) and the UK (Helfaya and Moussa 2017). Berthelot and Robert (2011) found a positive impact from CSR committee size on Canadian firms' environmental reporting.

However, some researchers also found insignificant impacts from CSR committees on CSR reporting (Alshbili et al. 2019; Dilling 2010; Elsayih et al. 2018; Michelon and Parbonetti 2012) and environmental reporting (Berthelot and Robert 2011; Rankin et al. 2011). Liao et al. (2015) and Berthelot and Robert (2011) included CSR committee, size, independence and meetings, and did not find any significant impacts on environmental reporting. Thus, CSR committee implementation and composition may represent a symbolic board of directors strategy. Prior research on the impact from CSR committees on CSR reporting found heterogeneous results, while most of the included studies indicated a positive impact. According to the research questions derived from the theoretical foundation, CSR committees may be a substantive or a symbolic CSR management tool within the board of directors. As some regimes already had introduced mandatory CSR reporting rules, inconclusive results between voluntary and mandatory CSR preparers are realistic.

We identified three moderator analyses on the CSR committee-CSR reporting link. Highly polluting Italian industries (Jaggi et al. 2018a) and environmentally sensitive UK industries (Helfaya and Moussa 2017) positively moderate the relationship. Based on a cross-country sample, Adnan et al. (2018) stated that CSR committees change the negative culture (power distance)-CSR reporting link into a positive relationship. 


\subsection{CSR committees and CSOs' impact on CSRA decisions}

We identified nine studies on CSR committees (7) and CSOs' (2) impact on CSRA. Ruhnke and Gabriel (2013) found a positive impact from CSR committees on CSRA in their cross-country study. Based on civil law regimes, Martinez-Ferrero and Garcia-Sanchez (2017) found a positive impact from CSR committee meetings on both CSRA and audit firms as CSRA providers. Peters and Romi (2015) reported similar results regarding CSR committee expertise in the US. Conversely, Al-Shaer and Zaman (2018) found a negative relationship in the context of UK firms. Soh and Martinov-Bennie (2018), in examining the Australian capital market, referred to internal audit reporting's influence with the CSR committee on annual internal work plans devoted to CSR assurance and consulting. The authors did not find any significant results. Kend's (2015) results are also inconclusive, as CSR committees in the UK and Australia did not impact CSRA, but audit firms as CSRA providers. Thus, in line with our results on CSR reporting and according to the research questions derived from our theoretical framework, the results on the link between CSR committees and CSRA decisions led to heterogeneous results, which might be based on different regulatory settings of a CSRA engagement, which have been analysed in different empirical contexts. Considering that the number of such studies remains low, we recommend future research on this topic. Regarding legitimacy theory, we cannot clearly decide whether the implementation of CSOs and CSR committees represents a symbolic or substantive management tool.

With regard to moderator analysis, Al-Shaer and Zaman (2018) stated that the negative link between CSR committees and CSRA is changed to a positive relationship by audit committee independence and expertise. Thus, the interdependencies between CSR committees and audit committees are crucial.

In line with prior CSR committee research, CSO studies are also heterogeneous in their results and of low amount. In the US context, as examined by Peters and Romi (2015), CSO implementation and CSO expertise are linked positively with CSRA. Although CSOs, as sustainable experts, did not prefer audit firms, they preferred consultants as CSRA providers. However, CSO implementation did not impact CSRA reporting, according to Rossi and Tarquinio in Italy (2017). Thus, the research findings neither clearly support nor reject the assumptions derived from upper-echelons theory.

\subsection{CSR committees and CSOs' impact on CSR performance}

We identified 19 studies on CSR committees (14) and CSOs' (5) impact on CSR and environmental performance. Thus, performance outputs represent the second highest effect in our literature review. With regard to CSR committee implementation, the majority found a positive impact on CSR performance. This results could be stated both in cross-country designs (Baraibar-Diez and Odriozola 2019; Birindelli et al. 2018) and in specific regimes in the US (Burke et al. 2019, based on CSR strengths) and in Australia (Biswas et al. 2018). Positive results also are 
related to environmental performance on a cross-country level (García Martín and Herrero 2019) for Turkey (Kilic and Kuzey 2019), the US (Dixon-Fowler et al. 2017; Walls et al. 2012) and the UK (Konadu 2017; Liao et al. 2015 based on carbon-emissions scope 1). Liao et al. (2015) referred to CDP participation in a UK sample and found a positive influence from CSR committee size, independence and meeting frequency. However, some researchers stated that CSR committees did not influence CSR performance (Burke et al. 2019; Lin et al. 2015 based on CSR concerns) or environmental performance (Konadu 2017 based on carbon emissions scope 2; Rodrigue et al. 2013; USA). In a cross-country design, Eberhardt-Toth (2017) found a positive impact from CSR committee independence, age and female chairs; a negative impact from CEO membership and size; and an insignificant impact from board chair membership on CSR performance. We also found heterogeneous results on the link between CSR committees and CSR performance, while most of the included studies found a positive relationship. Thus, there are indications that firms substantively use the implementation of CSR committees to strengthen their CSR activities. With regard to CSR performance, researchers include different databases with a variety of proxies. Moreover, we found country-specific differences and industry effects (e.g., environmentally sensitive industries) that could lead to inconclusive results. Thus, in line with legitimacy theory and stakeholder theory, there are indications that CSR committees are not used as a symbolic management tool, but substantially increase CSR performance.

We stress only one mediator analysis in our sample, in which CSR strategy mediates the relationship between CSR committees and CSR performance in a UK setting (Orazalin 2020).

Over the years, three studies also have included CSR committees as moderators of other corporate governance drivers of CSR performance. Benjamin et al.'s (2019) US study indicated that CSR committees negatively moderate the board independence-CSR performance link (sustainable supply chain responsibility). According to Baraibar-Diez et al. (2019), CSR committees in Europe positively moderate the link between CSR-related compensation and CSR performance. Furthermore, CSR committees in the US weaken the negative link between less-able CEOs and CSR performance (Garcia-Sanchez et al. 2019). Moreover, environmental team and board gender diversity (Konadu 2017) and firm performance (Lin et al. 2015) positively moderate the relationship between CSR committees and CSR/environmental performance.

In line with other effect variables, CSO studies are very scant, and their USrelated results are inconclusive. While Fu et al. (2020) noted a significant positive impact from CSO on CSR performance, Peters et al. (2019) did not find any significant link. However, CSO non-expertise decreased CSR performance. According to Kanashiro and Rivera (2019), CSO implementation and environmental performance are negatively linked. Thus, in line with legitimacy theory, it remains unclear whether the implementation of a CSO represents a symbolic or substantive management tool.

We also stress three studies that included moderator analyses of CSO implementation. Kanashiro and Rivera (2019) found that environmental regulatory pressure 
positively moderates the CSO-environmental performance link. According to Peters et al. (2019), prior CSR performance represents a moderator of the positive impact from CSOs on future CSR performance. Finally, Dixon-Fowler et al. (2017)'s study is exclusive, as both CSO and CSR committees are integrated into one research design. The authors found that CSOs moderate the positive influence on environmental performance from environmental stakeholder representation on CSR committees.

Table 2 contains a detailed description of all included studies.

\section{Discussion and contributions}

Since the financial crisis of 2008/09, many reform initiatives on sustainable corporate governance and sustainable management control were discussed and finalised from an international perspective (e.g., Feder and Weißenberger 2019; Ghosh et al. 2019; Johnstone 2019; Lingnau et al. 2019). Boards of directors are motivated to engage in implementing a sustainability management system and increasing their sustainability expertise. In recent empirical research, two main areas of institutionalised sustainability-related board expertise are differentiated: CSOs and CSR committees (e.g., Burke et al. 2019; Dixon-Fowler et al. 2017; Hussain et al. 2018; Kanashiro and Rivera 2019; Peters et al. 2019; Rodrigue et al. 2013; Strand 2013, 2014; Wiengarten et al. 2017). However, in light of the heterogeneous results in prior research and according to the research questions based on our theoretical framework, it remains unclear whether boards of directors include these institutions for intrinsic motivations to substantially increase CSR strategies within the firm, or use CSOs and CSR committees only as symbols to attract stakeholders. In light of greenwashing, information overload and unethical manager behaviour over the years, it is not surprising that empiricalquantitative research on sustainability-related board expertise and its CSR effects increased since the financial crisis. While literature reviews and meta-analyses on sustainable corporate governance already exist (e.g., Dienes et al. 2016; Elsakit and Worthington 2014; Hahn and Kühnen 2013), our review is the first to offer a comprehensive, theory-based framework (legitimacy theory, stakeholder theory and upper-echelons theory) on the link between CSR committees, CSOs and CSR outputs. As CSR outputs, we differentiated between CSR reporting, CSRA and CSR performance. Moreover, we were interested in the moderators and mediators that might influence the sustainability-related board expertise-CSR relationship, and we also recognise CSR committees and CSOs as moderators or mediators on the impact of other corporate governance variables on CSR.

Our review makes major contributions to the research field on CSR committees and CSOs. First, we structured this increasing research topic into items that separately analyse three heterogeneous CSR effects. Second, we provided a comprehensive list of variables and proxies used in the studies (cf. Table 2) and included their main statistical effects. In this context, we also included moderators and mediators, which were included in prior research designs. Furthermore, we presented the major effects within the research field based on our derived research framework. 
Finally, we presented a research agenda that addresses future research designs from a content, methodological and theoretical perspective. Our review also includes several implications for practice. We provided a summary of recent studies showing that CSR committees and CSOs have high relevance for PIEs that engage in CSR activities. In more detail, most included studies found a positive impact from CSR committees on both CSR reporting and CSR performance. Based on legitimacy theory, stakeholder theory and upper-echelons theory, we concluded that a positive link exists between CSOs and CSR committees, as well as CSR-related proxies (CSR reporting, CSRA). In light of the heterogeneity of prior research and the low number of studies, it remains unclear which effect CSOs exert on selected CSR-related proxies. Although this result may be explained via legitimacy theory, it is not in line with the assumptions derived by upper-echelons theory and stakeholder theory. Regarding CSR committees, most included studies found a positive impact on CSR performance and CSR reporting. Thus, in line with the assumption derived from stakeholder theory, there are indications that CSR committees not only are used as symbols in business practice, but also lead to substantive increases in CSR strategies. We cannot stress any comparable tendency on the link between CSR committees and CSRA. We also note that the number of studies on other CSR effects and on CSOs remains too low and is characterised by heterogeneous results. Furthermore, in this research field, major research gaps exist. Besides increased board awareness of sustainability-related board expertise, digital transformation (Reis et al. 2018) mainly will influence boards of directors' activities (e.g., blockchain, big data technologies) and may contribute to reduced greenwashing and increased efficiency in CSR strategies.

\section{Conclusion and opportunities for further research on CSR committees and CSOs}

\subsection{Content-related issues}

We see a variety of future research opportunities. First, we note that research on CSOs and the impact of sustainability-related board expertise on CSRA remains scant. To gain a deeper understanding of CSR effects, future studies should not only focus on environmental issues (e.g., carbon performance), but also analyse their influence on social performance and disclosure (e.g., diversity reporting), triple bottom line (TBL) reporting and integrated reporting (Velte and Stawinoga 2017b). Similar to how we noted that CSOs and CSR committees may be used as symbolic, sustainable corporate governance tools, more attention should be paid to the legitimacy approach towards specific CSO characteristics and CSR committee composition (e.g., independence, expertise, education, size, meetings, gender and cooperation with other corporate governance institutions, such as internal auditors, audit committees and external auditors). With regard to CSO research based on the upper-echelons approach, behavioural aspects also should be integrated (e.g., CSO overconfidence, narcissism, values or materialism) in line with recent CEO research (Tang et al. 2018). Furthermore, the connections between CSOs, CEOs and CFOs 
should be analysed. CSR strategies have gained much interest among sustainable investors over the years from an international perspective. Thus, the impact from CSOs and CSR committees on ownership structure and other stakeholder reactions (e.g., media pressure) represents a fruitful research pathway. In addition, effects other than CSR may be affected by sustainability-related board composition, e.g., reduced earnings, lower taxes or other financial consequences (e.g., increased financial performance, reduced cost of capital). Prior research mainly relies on the consequences of CSR committees and CSOs, with only a few addressing possible determinants (Gennari 2019; Gennari and Salvioni 2019).

\subsection{Theoretical issues}

While we identified the dominance of selected theories (legitimacy theory, stakeholder theory with regard to CSR committees and upper-echelons theory related to CSOs), some studies in our included sample did not rely on a specific theory (e.g., Dilling 2010). In addition, stakeholder theory and principal agent theory are used simultaneously to contrast the heterogeneous effects from sustainability-related board expertise on CSR. However, the combination of these two theories as stakeholder agency theory (Hill and Jones 1992) can be a useful theoretical contribution.

Moreover, we should note that behavioural agency theory has not been used in prior research on CSR committees and CSOs so far (Pepper and Gore 2015). As a result, further top management team actions depend on their perceived current positions. Bosse and Phillips (2016) further explained perceptions of fairness. Executives are bounded, self-interested actors; thus, they are driven not only by self-interest, but also are influenced by social norms, such as fairness or justification. A fair treatment by an agent will lead to increased CSR activities, but if bounded, selfinterested agents perceive their treatment as unfair, they demand additional compensation for the sake of (perceived) injustice (Bosse et al. 2009) and to engage in CSR activities.

Another theoretical approach that is highly relevant in gender diversity research is critical mass theory (Kanter 1977), which also can be useful in future studies on sustainability-related board expertise via CSR committees and CSOs. In light of substantive CSR strategies, this theory can lead to further discussions as to whether having one person on the top management team as CSO is enough to implement a successful sustainable management system. Moreover, critical mass theory may contribute to future analyses on CSR committees' composition, e.g., how many sustainability experts need to be included on the committee, or deciding whether the CSR committee should comprise executive or non-executive directors.

\subsection{Methodological issues}

Prior research is related to many methodological restrictions that should be addressed in this section. First, sustainability-related board composition often is used as a dummy variable by indicating whether a CSR committee or CSO exists (yes $=1$, 
no $=0$ ). There should be more concentration on committee composition, CSO characteristics and incentives, especially to differentiate symbolic from substantive use of these sustainable corporate governance mechanisms. The recognition of dummy variables, such as whether firms have implemented CSR committees or CSOs, is linked with limited explanatory power, as the researcher cannot evaluate symbolic or substantive use of institutionalised board expertise. In line with prior corporate governance research, a positive connection exists among board efficiency variables, e.g., expertise, its members' independence or activity and monitoring quality in line with stakeholders' interests (Dienes et al. 2016). In particular, sustainability expertise and board members' independence will lead to a strict focus on CSR-related monitoring activities and should lead to more substantive CSR activities and increased CSR outputs. These composition proxies lower the risk of greenwashing behaviour and information overload as symbolic uses of CSR institutions. Moreover, symbolic or substantive use of CSR committees and CSOs may be better analysed by including CSR assurance as CSR outputs. Symbolic use of CSR committees and CSOs is linked with a reduced management incentive to engage an external party for CSRA.

Second, we noticed few moderator analyses and only one mediator analysis in our included studies. There should be more research attention paid to CSR committees and CSOs as moderators and mediators of other corporate governance variables. Moreover, the interactions between CSR committees and CSOs should be addressed in future research designs. Third, researchers should conduct cross-country studies and include country-related governance items (e.g., enforcement strength, shareholder rights, case vs. code law regimes, and one- vs. two-tiered systems) and cultural aspects (Hofstede and Bond 1984). Fourth, as greenwashing policies and information overload may be linked to symbolic use of CSR committees and CSOs, moderators or subsamples of firms that include environmental management systems or ISO 14,000 certification are most useful (Chen 2005; Melnyk et al. 2003). Fifth, many of our included studies do not explicitly address endogeneity concerns, e.g., omitted variable bias, simultaneity or measurement error. Thus, future research should analyse bidirectional relationships between sustainability-related board composition and CSR, and implement GMM and instrumental variables, the Heckman approach or propensity-score matching (Wintoki et al. 2012). As the implementation of CSR committees and CSOs is voluntary in most regimes, a selection bias could be realistic.

Propensity score matching (Rosenbaum and Rubin 1983; Shipman et al. 2017), sometimes in combination with a difference-in-differences approach, was proposed to increase the validity of empirical-quantitative research. Propensity score matching addressed potential nonlinearities in the control variables and composed a control group that was similar to the treatment companies, but did not implement CSR committees and CSOs during the sample period. The difference-in-differences method differentiates the effect from adopting CSR committees and CSOs from the effect of firm characteristics, which normally is associated with the implementation of these board variables. Reversed causality and omitted variables also are problematic in empirical-quantitative research on sustainable corporate governance. While valid instrumental variables should induce changes in the proxies related to CSR committees and CSOs, they do not independently affect CSR outputs, allowing the 
researcher to uncover these proxies' causal effect (Wintoki et al. 2012). With regard to CSR committee composition, prior studies included linear regression models, but a non-linear relationship ((inverted) U-shape) may be more realistic. Sixth, most of our included studies relied on external CSR and corporate governance databases. A mixed model approach is recommended to analyse corporate governance and sustainability reports, as well as to increase the validity of CSO, CSR committee and CSR variables. Empirical-qualitative research via interviews, surveys and case studies also is important as complementary research designs to analyse organisational and processual aspects and challenges from internal and external stakeholders' perspectives (investors, customers, suppliers).

\section{Limitations of our analysis}

As a key limitation of our study, our vote counting approach is linked to limited validity, as we only analysed the number of significances and did not take sample or effect sizes into account. These restrictions might be overcome by a quantitative meta-analysis, but our CSR measures are too heterogeneous to conduct an overall meta-analysis. Furthermore, the number of prior studies on sustainability-related board composition remains too low to conduct a separate meta-analysis on specific variables (e.g., on CSOs). As quantitative meta-analysis has been embraced increasingly as a useful research method in sustainability studies in recent years (Fifka 2013; Lu and Taylor 2016), we expect to see more research activity concerning sustainability-related board expertise in the future, along with meta-analyses on sustainable corporate governance to gain importance in statistically summarising existing research and increasing the quality of research results on CSOs and CSR committees.

\section{Implications for business practice}

Our results carry several implications for business practice. As CSR committees and CSOs may be implemented for both substantive and symbolic CSR activities, these institutions' role within boards of directors must be analysed further on a processual level. Managers should analyse the CSR committee's composition and the CSO's personal attitude. The composition, and especially the expertise, of the CSR committee and CSO should be evaluated and clearly described in the corporate governance or sustainability report. Stakeholders demand evaluations of these positions' individual profiles. The reports should inform stakeholders on the practical and/or theoretical CSR-related experiences of all CSR committee members and the CSO.

From an international perspective, CSR committees may have a different function within a one-tier, compared with a two-tier system. With regard to the two-tier system, the firm must decide whether the CSR committee is part of the management board (with an emphasis on leadership) and/or part of the supervisory board (with an emphasis on monitoring duties). Moreover, the connection between CSR 
committees and other board committees, e.g., audit or risk committees, is of crucial relevance. As some stakeholder groups, e.g., sustainable investors, demand an integrated report with a combined analysis of financial and nonfinancial aspects, it can be useful to implement combined CSR, audit or risk committees to increase corporate boards' motivations to implement integrated reporting (Velte and Stawinoga 2017b). Regarding the CSO, companies may question a possible dual role comprising $\mathrm{CEO} / \mathrm{CFO}$ and CSO positions to increase CSOs' power and their influence over CSR activities. However, power also can lead to opportunistic behaviours and decrease stakeholders' interest in CSR activities.

If a company has implemented a CSO and CSR committee as well, a separation between the sustainability-related tasks seems appropriate. As the CSO is a regular part of the top management team, this position should handle primarily CSRrelated tasks with a strategic focus for the respective company. However, as the CSR committee regularly plays an assistant role for the board, this committee primarily should handle operative CSR-related tasks. If a company has implemented either a CSO or CSR committee, a clear separation between strategic and operative CSRrelated tasks is not possible. Thus, the CSR committee should comprise specialists in the fields of strategic and operative CSR-related matters. Otherwise, if a CSR committee does not exist, the CSO should enlarge strategic and operative CSRrelated tasks as well. Consequently, the CSO should have experience in both areas of CSR-related tasks.

Funding Open Access funding enabled and organized by Projekt DEAL.

Open Access This article is licensed under a Creative Commons Attribution 4.0 International License, which permits use, sharing, adaptation, distribution and reproduction in any medium or format, as long as you give appropriate credit to the original author(s) and the source, provide a link to the Creative Commons licence, and indicate if changes were made. The images or other third party material in this article are included in the article's Creative Commons licence, unless indicated otherwise in a credit line to the material. If material is not included in the article's Creative Commons licence and your intended use is not permitted by statutory regulation or exceeds the permitted use, you will need to obtain permission directly from the copyright holder. To view a copy of this licence, visit http://creativecommons.org/licen ses/by/4.0/.

\section{References}

Abbott, L. J., Parker, S., \& Peters, G. F. (2004). Audit committee characteristics and restatements. Auditing: A Journal of Practice \& Theory, 23(1), 69-87.

Adel, C., Hussain, M., Mohamed, E., \& Basuony, M. (2019). Is corporate governance relevant to the quality of corporate social responsibility disclosure in large European companies? International Journal of Accounting \& Information Management, 27(2), 301-332.

Adnan, S. M., Hay, D., \& Staden, C. J. (2018). The influence of culture and corporate governance on corporate social responsibility disclosure: A cross country analysis. Journal of Cleaner Production, $198,820-832$.

Al-Shaer, H., \& Zaman, M. (2018). Credibility of sustainability reports: The contribution of audit committees. Business Strategy and the Environment, 27(7), 973-986.

Al-Shaer, H., \& Zaman, M. (2019). CEO compensation and sustainability reporting assurance: Evidence from the UK. Journal of Business Ethics, 158(1), 233-252. 
Alshbili, I., Elamer, A. A., \& Beddewela, E. (2019). Ownership types, corporate governance and corporate social responsibility disclosures: Empirical evidence from a developing country. Accounting Research Journal, 33(1), 148-166.

Amran, A., Lee, S. P., \& Devi, S. S. (2014). The influence of governance structure and strategic corporate social responsibility toward sustainability reporting quality. Business Strategy and the Environment, 23(4), 217-235.

Baraibar-Diez, E., \& Odriozola, M. D. (2019). CSR committees and their effect on ESG performance in UK, France, Germany, and Spain. Sustainability, 11(18), 5077.

Baraibar-Diez, E., Odriozola, M. D., \& Fernandez Sanchez, J. L. (2019). Sustainable compensation policies and its effect on environmental, social and governance scores. Corporate Social Responsibility and Environmental Management, 26(6), 1457-1472.

Benjamin, S., Mansi, M., Pandey, R. (2019). Board gender composition, board independence and sustainable supply chain responsibility. Accounting and Finance (online first)

Berthelot, S., \& Robert, A. M. (2011). Climate change disclosures: An examination of Canadian oil and gas firms. Issues in Social and Environmental Accounting, 5(1/2), 106-123.

Birindelli, G., Dell'Atti, S., Iannuzzi, A. P., \& Savioli, M. (2018). Composition and activity of the board of directors: Impact on ESG performance in the banking system. Sustainability, 10(12), 4699.

Biswas, P. K., Mansi, M., \& Pandey, R. (2018). Board composition, sustainability committee and corporate social and environmental performance in Australia. Pacific Accounting Review, 30(4), $517-540$.

Bosse, D. A., \& Philipps, R. A. (2016). Agency theory and bounded self-interest. Academy of Management Review, 41(2), 276-297.

Bosse, D. A., Philipps, R. A., \& Harrison, J. S. (2009). Stakeholders, reciprocity, and firm performance. Strategic Management Journal, 30(4), 447-456.

Bruynseels, L., \& Cardinaels, E. (2014). The audit committee: Management watchdog or personal friend of the CEO? The Accounting Review, 89(1), 113-145.

Burke, J. J., Hoitash, R., \& Hoitash, U. (2019). The heterogeneity of board-level sustainability committees and corporate social performance. Journal of Business Ethics, 154(4), 1161-1186.

Byron, K., \& Post, C. (2016). Women on boards of directors and corporate social performance. A metaanalysis. Corporate Governance: An International Review, 24(4), 428-442.

Carpenter, M. A., Geletkanycz, M. A., \& Sanders, W. G. (2004). Upper echelons research revisited: Antecedents, elements, and consequences of top management team composition. Journal of Management, 30(6), 749-778.

Chen, C. C. (2005). Incorporating green purchasing into the frame of ISO 14000. Journal of Cleaner Production, 13(9), 927-933.

Combs, J. G., Ketchen, D. J., Crook, T. R., \& Roth, P. L. (2011). Assessing cumulative evidence within 'macro' research: Why meta-analysis should be preferred over vote counting. Journal of Management Studies, 48(1), 178-197.

Cucari, N., De Falco, S., \& Orlando, B. (2018). Diversity of boards of directors and environmental social governance: Evidence from Italian listed companies. Corporate Social Responsibility and Environmental Management, 25(3), 250-266.

Dahlsrud, A. (2008). How corporate social responsibility is defined: An analysis of 37 definition. Corporate Social Responsibility and Environmental Management, 15(1), 1-13.

Deegan, C. (2002). The legitimising effect of social and environmental disclosures: A theoretical foundation. Accounting, Auditing \& Accountability Journal, 15(3), 282-311.

Denyer, D., \& Tranfield, D. (2009). Producing a systematic review. In D. Buchanan \& A. Bryman (Eds.), The Sage handbook of organizational research methods (pp. 671-689). London: Sage.

Denyer, D., Tranfield, D., \& van Aken, J. E. (2008). Developing design propositions through research synthesis. Organization Studies, 29(3), 393-413.

Dienes, D., Sassen, R., \& Fischer, F. (2016). What are the drivers of sustainability reporting? A systematic review. Sustainability Accounting, Management and Policy Journal, 7(2), 154-189.

Dilling, P. (2010). Sustainability reporting in a global context: What are the characteristics of corporations that provide high quality sustainability reports. International Business \& Economics Research Journal, 9(1), 19-30.

Dixon-Fowler, H. R., Ellstrand, A. E., \& Johnson, J. L. (2017). The role of board environmental committees in corporate environmental performance. Journal of Business Ethics, 140(3), 423-438.

Dyllick, T., \& Muff, K. (2016). Clarifying the meaning of sustainable business: Introducing a typology from business-as-usual to true business sustainability. Organization \& Environment, 29(2), 156-174. 
Eberhardt-Toth, E. (2017). Who should be on a board corporate social responsibility committee? Journal of Cleaner Production, 140(3), 1926-1935.

Eberhardt-Toth, C., Gendron, C., \& Ramboarisata, L. (2019). Determinants of the presence of CSR committees within European boards of directors. Revue de l'Organisation Responsible, 14(1), 33-49.

Elsakit, O. M., \& Worthington, A. C. (2014). The impact of corporate characteristics and corporate governance on corporate social and environmental disclosure: A literature review. International Journal of Business and Management, 9(9), 1-15.

Elsayih, J., Tang, Q., \& Lan, Y. C. (2018). Corporate governance and carbon transparency: Australian evidence. Accounting Research Journal, 31(3), 405-422.

Endrikat, J., de Villiers, C., Guenther, T., \& Guenther, E. (2020). Board characteristics and corporate social responsibility: A meta-analytic investigation. Business and Society. https://doi. org/10.1177/0007650320930638.

Engert, S., Rauter, R., \& Baumgartner, R. J. (2016). Exploring the integration of corporate sustainability into strategic management: A literature review. Journal of Cleaner Production, 112(4), 2833-2850.

Faisal, F., \& Achmad, T. (2014). Internal contextual factors influencing the extent of environmental disclosure. International Journal of Managerial and Financial Accounting, 6(4), 357-374.

Fassin, Y., \& Gosselin, D. (2011). The collapse of a European bank in the financial crisis: An analysis from stakeholder and ethical perspectives. Journal of Business Ethics, 102(2), 169-191.

Feder, M., \& Weißenberger, B. E. (2019). Understanding the behavioral gap: Why would managers (not) engage in CSR-related activities? Journal of Management Control, 30(1), 5-24.

Fernando, S., \& Lawrence, S. (2014). A theoretical framework for CSR practices: Integrating legitimacy theory, stakeholder theory and institutional theory. Journal of Theoretical Accounting Research, 10, 149-178.

Fifka, M. (2012). The development and state of research on social and environmental reporting in global comparison. Journal für Betriebswirtschaft, 62, 45-84.

Fifka, M. (2013). Corporate responsibility reporting and its determinants in comparative perspective: A review of the empirical literature and a meta-analysis. Business Strategy and the Environment, 22(1), 1-35.

Freeman, R. E. (1984). Strategic management: A stakeholder approach. Boston: Pitman.

Freeman, R. E., Harrison, J. S., Wicks, A. C., Parmar, B. L., \& de Colle, S. (2010). Stakeholder theory: The state of the art. Cambridge: Cambridge University Press.

Fu, R., Tang, Y., \& Chen, G. (2020). Chief sustainability officers and corporate social (Ir)responsibility. Strategic Management Journal, 41(4), 656-680.

Fuente, J. A., Garcia-Sanchez, I. M., \& Lozano, M. B. (2017). The role of the board of directors in the adoption of GRI guidelines for the disclosure of CSR information. Journal of Cleaner Production, $141,737-750$.

Gallego-Alvarez, I., \& Pucheta-Martinez, M. C. (2020). Corporate social responsibility reporting and corporate governance mechanisms: A international outlook from emerging countries. Business Strategy and Development, 3(1), 77-97.

Garcia-Blandon J, Castillo-Merino D, Argilés-Bosch JM, Ravenda D (2020) Board-level ethics committees in large European firms. Business Ethics: A European Review (online first)

García Martín, C. J., \& Herrero, B. (2019). Do board characteristics affect environmental performance? A study of EU firms. Corporate Social Responsibility and Environmental Management, 27(1), 74-94.

Garcia-Sanchez, I. M., Nazim, H., \& Martinez-Ferrero, J. (2019). An empirical analysis of the complementarities and substitutions between effects of CEO ability and corporate governance on socially responsible performance. Journal of Cleaner Production, 215, 1288-1300.

Garcia-Torea, N., Fernandez-Feijoo, B., \& Mdl, C. (2016). Board of directors' effectiveness and the stakeholder perspective of corporate governance: Do effective boards promote the interests of shareholders and stakeholders? BRQ Business Research Quarterly, 19(4), 246-260.

Gennari, F., \& Salvioni, D. M. (2019). CSR committees on boards: The impact of the external country level factors. Journal of Management and Governance, 23(3), 759-785.

Gennari, F. (2019). How to lead the board of directors to a sustainable development of business with the CSR committees. Sustainability, 11(24), 6987.

Ghosh, B., Herzig, C., \& Mangena, M. (2019). Controlling for sustainability strategies: Findings from research and directions for the future. Journal of Management Control, 30(1), 5-24.

Guan, J., \& Noronha, C. (2013). Corporate social responsibility reporting research in the Chinese academia: A critical review. Social Responsibility Journal, 9(1), 33-55. 
Hahn, R., \& Kühnen, M. (2013). Determinants of sustainability reporting: A review of results, trends, theory, and opportunities in an expanding field of research. Journal of Cleaner Production, 59, $5-21$.

Hambrick, D. C. (2007). Upper echelons theory: An update. Academy of Management Review, 32(2), 334-343.

Hambrick, D. C., \& Mason, P. A. (1984). Upper echelons: The organization as a reflection of its top managers. Academy of Management Review, 9(2), 193-206.

Harrison, J. R. (1987). The strategic use of corporate board committees. California Management Review, $30(1), 109-125$.

Helfaya, A., \& Moussa, T. (2017). Do board's corporate social responsibility strategy and orientation influence environmental sustainability disclosure? UK Evidence. Business Strategy and the Environment, 26(8), 1061-1077.

Hill, C. W. L., \& Jones, T. M. (1992). Stakeholder-agency Theory. Journal of Management Studies, 29(2), 131-154.

Hofstede, G., \& Bond, M. H. (1984). Hofstede's culture dimensions: an independent validation using Rokeach's value survey. Journal of Cross-Cultural Psychology, 15(4), 417-433.

Hussain, N., Rigoni, U., \& Orij, R. P. (2018). Corporate governance and sustainability performance: Analysis of triple bottom line performance. Journal of Business Ethics, 149(2), 411-432.

Jaggi, B., Allini, A., Macchioni, R., \& Zagaria, C. (2018). The factors motivating voluntary disclosure of carbon information: Evidence based on Italian listed companies. Organization \& Environment, 31(2), 178-202.

Jaggi, B., Allini, A., Macchioni, R., \& Zampella, A. (2018). Do investors find carbon information useful? Evidence from Italian firms. Review of Quantitative Finance \& Accounting, 50(4), 1031-1056.

Jain, T., \& Jamali, D. (2016). Looking inside the black box: The effect of corporate governance on corporate social responsibility. Corporate Governance: An International Review, 24(3), 253-273.

Jamali, D., Safieddine, A. M., \& Rabbath, M. (2008). Corporate governance and corporate social responsibility synergies and interrelationships. Corporate Governance: An International Review, 16(5), 443-459.

Johnstone, . (2019). Theorising and conceptualisierung the sustainability control system for effective sustainability management. Journal of Management Control, 30(1), 25-64.

Kanashiro, P., \& Rivera, J. (2019). Do chief sustainability officers make companies greener? The moderating role of regulatory pressures. Journal of Business Ethics, 155(3), 687-701.

Kanter, R. M. (1977). Some effects of proportions on group life. In P. P. Rieker \& E. Carmen (Eds.), The gender gap in psychotherapy (pp. 53-78). Boston: Springer.

Kend, M. (2015). Governance, firm-level characteristics and their impact on the client's voluntary sustainability disclosures and assurance decisions. Sustainability Accounting, Management and Policy Journal, 6(1), 54-78.

Khlif, H., \& Chalmers, K. (2015). A review of meta-analytic research in accounting. Journal of Accounting Literature, 35(1), 1-27.

Khlif, H., Hussainey, K., \& Achek, I. (2015). The effect of national culture on the association between profitability and corporate social and environmental disclosure. A meta-analysis. Meditari Accountancy Research, 23(3), 296-321.

Kilic, M., \& Kuzey, C. (2019). The effect of corporate governance on carbon emission disclosures: Evidence from Turkey. International Journal of Climate Change Strategies and Management, 11(1), 35-53.

Konadu, R. (2017). Gender diversity impact on corporate social responsibility (CSR) and greenhouse gas emissions in the UK. Economics and Business Review, 3(17), 127-148.

Liao, L., Luo, L., \& Tang, Q. (2015). Gender diversity, board independence, environmental committee and greenhouse gas disclosure. The British Accounting Review, 47(4), 409-424.

Light, R., \& Smith, P. (1971). Accumulating evidence: Procedures for resolving contradictions among different research studies. Harvard Educational Review, 41(4), 429-471.

Lin, P. T., Li, B., \& Bu, D. (2015). The relationship between corporate governance and community engagement: Evidence from the Australian mining companies. Resources Policy, 43, 28-39.

Lingnau, V., Fuchs, F., \& Beham, F. (2019). The impact of sustainability in coffee production on consumers' willingmess to pay-new evidence from the field of ethical consumption. Journal of Management Control, 30(1), 65-93.

Lu, W. L., \& Taylor, M. E. (2016). Which factors moderate the relationship between sustainability performance and financial performance? A meta-analysis study. Journal of International Accounting Research, 15(1), 1-15. 
Mahmood, Z., Kouser, R., Ali, W., Ahmad, Z., \& Salman, T. (2018). Does corporate governance affect sustainability disclosure? A mixed methods study. Sustainability, 10(1), 207.

Mahoney, L. S., Thorne, L., Cecil, L., \& LaGore, W. (2013). A research note on standalone corporate social responsibility reports. Critical Perspectives on Accounting, 24(1), 350-359.

Majumder, T. H., Akter, A., \& Li, X. (2017). Corporate governance and corporate social disclosures: A metaanalytical review. International Journal of Accounting \& Information Management, 25(4), 434-458.

Malik, M. (2015). Value-enhancing capabilities of CSR: A brief review of contemporary literature. Journal of Business Ethics, 127(2), 419-438.

Maroun, W. (2020). A conceptual model for understanding corporate social responsibility assurance practice. Journal of Business Ethics, 161(2), 187-209.

Martinez-Ferrero, J., \& Garcia-Sanchez, I. (2017). Sustainability assurance and assurance providers: Corporate governance determinants in stakeholder-oriented countries. Journal of Management \& Organization, 23(5), 647-670.

Melnyk, S. A., Sroufe, R. P., \& Calantone, R. (2003). Assessing the impact of environmental management systems on corporate social performance. Journal of Operations Management, 21(3), 329-351.

Michelon, G. (2011). Sustainability disclosure and reputation: A comparative study. Corporate Reputation Review, 14(2), 79-96.

Michelon, G., \& Parbonetti, A. (2012). The effect of corporate governance on sustainability disclosure. Journal of Management and Governance, 16(3), 477-509.

Miller, K., \& Serafeim, G. (2014). Chief sustainability officers: Who are they and what do they do? In R. Henderson, R. Gulati, \& M. Tushman (Eds.), Leading Sustainable Change. Oxford: Oxford University Press. (SSRN: https://ssrncom/abstract=2411976).

Mitchell, R. K., Agle, B. R., \& Wood, D. J. (1997). Toward a theory of stakeholder identification and salience: Defining the principle of who and what really counts. The Academy of Management Review, 22(4), 853-886.

Nagel, D., Koep, L., Guenther, E., \& Guenther, T. (2019). "Diesel-gate" in risk-reporting-An analysis of risk communication in annual reports using the example of a disruptive event. Sustainability Management Forum/Nachhaltigkeits Management Forum, 27(3-4), 151-163.

Orazalin, N. (2020). Do board sustainability committees contribute to corporate environmental and social performance? The mediating role of corporate social responsibility strategy. Business Strategy and the Environment, 29(1), 140-153.

Ortas, E., Alvarez, I., \& Zubeltzu, E. (2017). Firms' board independence and corporate social performance: A meta-analysis. Sustainability, 9(6), 1-26.

Patten, D. M. (2019). Seeking legitimacy. Sustainability Accounting, Management and Policy Journal, 11(6), 1009-1021.

Pepper, A., \& Gore, J. (2015). Behavioural agency theory: New foundations for theorizing about executive compensation. Journal of Management, 41(4), 1045-1068.

Peters, G. F., \& Romi, A. M. (2015). The association between sustainability governance characteristics and the assurance of corporate sustainability reports. Auditing, 34(1), 163-198.

Peters, G. F., Romi, A. M., \& Sanchez, J. M. (2019). The influence of corporate sustainability officers on performance. Journal of Business Ethics, 159(4), 1065-1087.

Pizzi, S., Venturelli, A., Caputo, F. (2020). The “comply-or-explain” principle in directive 95/2014/EU. A rhetorical analysis of Italian PIEs. Sustainability Accounting, Management and Policy Journal (online first)

Prinsloo, A., Maroun, W. (2020). An exploratory study on the components and quality of combined assurance in an integrated and or sustainability reporting setting. Sustainability Accounting, Management and Policy Journal (online first)

Pucheta-Martinez, M., \& Gallego-Alvarez, I. (2019). An international approach of the relationship between board attributes and the disclosure of corporate social responsibility issues. Corporate Social Responsibility and Environmental Management, 26(3), 612-627.

Rankin, M., Windsor, C., \& Wahyuni, D. (2011). An investigation of voluntary corporate greenhouse gas emissions reporting in a market governance system: Australian evidence. Accounting, Auditing \& Accountability Journal, 24(8), 1037-1070.

Rao, K., \& Tilt, C. (2016). Board composition and corporate social responsibility: The role of diversity, gender, strategy and decision making. Journal of Business Ethics, 138, 327-347.

Reinhardt, R., Christodoulou, I., García, B. A., \& Gassó-Domingo, S. (2020). Sustainable business model archetypes for the electric vehicle battery second use industry: Towards a conceptual framework. Journal of Cleaner Production, 254, 119994. 
Reis, J., Amorim, M., Melão, N., \& Matos, P. (2018). Digital transformation: A literature review and guidelines for future research. In Á. Rocha, H. Adeli, L. P. Reis, \& S. Costanzo (Eds.), Trends and advances in information systems and technologies WorldCIST'18 2018. Advances in intelligent systems and computing (745th ed., pp. 411-421). Cham: Springer.

Rodrigue, M., Magnan, M., \& Cho, C. H. (2013). Is environmental governance substantive or symbolic? An empirical investigation. Journal of Business Ethics, 114(1), 107-129.

Rossi, A., \& Tarquinio, L. (2017). An analysis of sustainability report assurance statements: Evidence from Italian listed companies. Managerial Auditing Journal, 32(6), 578-602.

Rosenbaum, P. R., \& Rubin, D. B. (1983). The central role of the propensity score in observational studies for casual effects. Biometrika, 70(1), 41-55.

Ruhnke, K., \& Gabriel, A. (2013). Determinants of voluntary assurance on sustainability reports: An empirical analysis. Journal of Business Economics, 83(9), 1063-1091.

Ruigrok, W., Peck, S., Tacheva, S., Greve, P., \& Hu, Y. (2006). The determinants and effects of board nomination committees. Journal of Management \& Governance, 10, 119-148.

Salzmann, O., Ionescu-Somers, A., \& Steger, U. (2005). The business case for corporate sustainability: Literature review and research options. European Management Journal, 23(1), 27-36.

Schulz, J. F. (2017). Does greater disclosure of information on CSR performance improve analyts' forecast accuracy? Zeitschrift für Umweltpolitik \& Umweltrecht, 2, 134-160.

Shipman, J. E., Swanquist, Q. T., \& Whited, R. L. (2017). Propensity score matching in accounting research. The Accounting Review, 92(1), 213-244.

Shocker, A. D., \& Sethi, S. P. (1973). An approach to incorporating societal preferences in developing corporate action strategies. California Management Review, 15(4), 97-105.

Soh, D. S. B., \& Martinov-Bennie, N. (2018). Factors associated with internal audit's involvement in environmental and social assurance and consulting. International Journal of Auditing, 22(3), 404-421.

Spence, M. (1973). Job Market signaling. The Quarterly Journal of Economics, 87(3), 355-374.

Strand, R. (2013). The chief officer of corporate social responsibility: A study of its presence in top management teams. Journal of Business Ethics, 112(4), 721-734.

Strand, R. (2014). Strategic leadership of corporate sustainability. Journal of Business Ethics, 123(4), 687-706.

Tang, Y., Mack, D. Z., \& Chen, G. (2018). The differential effects of CEO narcissism and hubris on corporate social responsibility. Strategic Management Journal, 39(5), 1370-1387.

van Beurden, P., \& Gössling, T. (2008). The worth of values-A literature review on the relation between corporate social and financial performance. Journal of Business Ethics, 82, 407.

Velte, P. (2017). Does board composition have an impact on CSR reporting? Problems and Perspectives in Management, 15(2), 19-35.

Velte, P. (2019a). Do CEO incentives and characteristics influence corporate social responsibility (CSR) and vice versa? A literature review. Social Responsibility Journal, 16, 1293-1323.

Velte, P. (2019b). Does board composition influence CSR reporting? A meta-analysis. Corporate Ownership \& Control, 16(2), 48-59.

Velte, P., \& Stawinoga, M. (2017a). Empirical research on corporate social responsibility assurance (CSRA): A literature review. Journal of Business Economics, 87(8), 1017-1066.

Velte, P., \& Stawinoga, M. (2017b). Integrated reporting: The current state of empirical research, limitations and future research implications. Journal of Management Control, 28(3), 275-320.

Waldman, D. A., Siege, D., \& Javidan, M. (2006). Components of CEO transformational leadership and corporate social responsibility. Journal of Management Studies, 43(8), 1703-1725.

Walls, J. L., Berrone, P., \& Phan, P. H. (2012). Corporate governance and environmental performance: Is there really a link? Strategic Management Journal, 33(8), 885-913.

Wiengarten, F., Lo, C. K. Y., \& Lam, J. Y. K. (2017). How does sustainability leadership affect firm performance? The choices associated with appointing a chief officer of corporate social responsibility. Journal of Business Ethics, 140(3), 477-493.

Wintoki, M. B., Linck, J. S., \& Netter, J. M. (2012). Endogeneity and the dynamics of internal corporate governance. Journal of Financial Economics, 105(3), 581-606.

Publisher's Note Springer Nature remains neutral with regard to jurisdictional claims in published maps and institutional affiliations. 


\section{Affiliations}

\section{Patrick Velte $^{1}$ D $\cdot$ Martin Stawinoga ${ }^{2}$}

$\triangle$ Patrick Velte

velte@leuphana.de

Martin Stawinoga

martin.stawinoga@th-owl.de

1 Institute of Management, Accounting and Finance (IMAF), Leuphana University of Lüneburg, Universitaetsallee 1, 21335 Lüneburg, Germany

2 Department of Business Administration and Economics, OWL University of Applied Sciences and Arts, Campusallee 12, 32657 Lemgo, Germany 